\title{
A Sui Dynasty (581-618) Iron Buddha: The Tale of Two Filial Sons
}

\author{
Paul G. Fendos Jr. ${ }^{1}$ \\ ${ }^{1}$ Minnesota State System, Chinese Studies, USA \\ Correspondent: Paul G. Fendos Jr., Minnesota State System, Chinese Studies, USA. E-mail: \\ Paul.Fendos@normandale.edu,pgfendos@yahoo.com \\ Received: October 21, 2017 \\ Accepted: November 17, 2016 \\ Online Published: December 8, 2017 \\ doi:10.5539/ach.v10n1p19 \\ URL: http://dx.doi.org/10.5539/ach.v10n1p19
}

\begin{abstract}
This article aims to ascertain the date and significance of what appears to be a Sui Dynasty (581-618) Iron Buddha by closely examining the artifact and the inscription on it. After a preliminary attempt to determine the 'style' of the Iron Buddha, more in-depth comparative analyses of it are carried out that focus on reconstructed dynastic calendars and the sexagenary dates in them, Buddhist iconography from the same period and the formulaic narrative and prayer-like entreaty passages found on them, and a companion Stone Guanyin piece located in the Detroit Institute of Arts. Summing up the results, in addition to substantiating the inscribed date found on the Iron Buddha, these analyses demonstrate that the Iron Buddha and Stone Guanyin were part of a larger story, one that was being played out during the Northern \& Southern Dynasties period, when Chinese social order and the Confucian ideology supporting it were declining, replaced in many areas by the growing influence of Daoism and Buddhism. This story centers on the tale of two filial sons who commissioned these pieces, hoping, in still following the centuries-long Confucian tradition, to honor their deceased Father, while doing so within the context of a rising Buddhist worldview, one in which they wished him freedom from pain and re-birth in a better place.
\end{abstract}

Keywords: Sui Dynasty, Buddhist sculpture, Buddhist thought, dynastic calendars, sexagenary dates

\section{Introduction}

An Iron Buddha discovered near the Jin Ancestral Temple, located in one of the historic centers of early Buddhist culture in northern China (Note 1), carries an inscription on its back dating it to the year 581 and the beginning of the Sui Dynasty (581-618). Opinions on the artifact among museum curators, online art appraisers, and even some scholars of traditional China are diverse, making it difficult to form any kind of consensus on exactly how the piece should be dated and what its historical significance might be. A radio-carbon dating lab was consulted, with the hope that it might be able to better place the Iron Buddha within a clear historical timeline, but such tests suggested an impossible date of approximately 24,000 YA-something that resulted from contamination of the iron by the coke used for heat during the manufacturing process (International Chemical Analysis) (Note 2). However, a close look at both the physical characteristics and style of the icon, along with an analysis of the inscription on its back, turned out to be much more useful, allowing for the creation of background context, and ultimately leading to a story of two filial sons from the late $6^{\text {th }}$ century trying to honor their deceased father.

\section{Facts and Conjecture}

\subsection{Dimensions \& Condition of Statue}

The Iron Buddha weighs about 2.3 kilos ( 5 pounds) and has a height of 28.5 centimeters ( 11 inches), a width of 19 centimeters ( 7 inches), and a breadth of 10.5 centimeters (4 inches) (Figure 1). It consists of three interconnected cast-iron pieces that were created separately in what were probably clay molds: a foundation seat, the Buddha, and a back piece (Note 3). It is in generally very good condition, coated with what looks to be a thin layer of dark/black resin or paint that has worn off on some protruding edges or bumps. There is some degree of oxidization on top of the resin/paint, but no real corrosion except inside the hollow statue, where one can find both flaking rust and patina. The Iron Buddha gives off a somewhat musty, burnt smell, perhaps suggesting long-term exposure to smoke, maybe incense. Some areas where different parts of the statue are joined seem to swell and look to be weakening (Note 4), and overall the statue looks to be in need of a cleaning (something not done). 


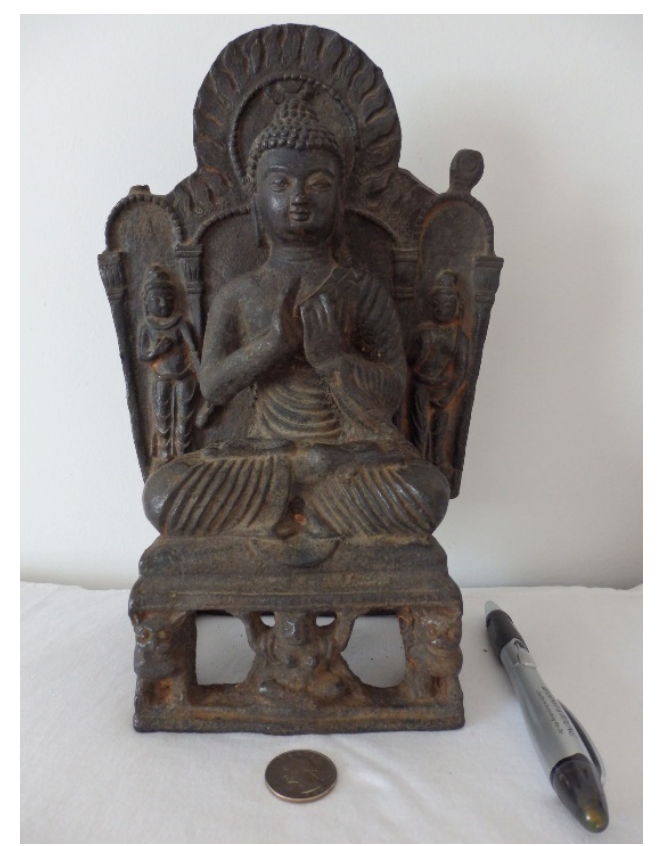

Figure 1. Chinese Iron Buddha. (Fendos 2016). See Appendices 1, 2, and 3-4 for close-up views

\subsection{Style of Iron Buddha}

The statue is best described as a 'seated Buddha' and shares many of the characteristics of Fong Chow's 'Stage 3' Seated Buddha sculpture style, which dates to the Northern Qi (550-577) and Northern Zhou (577-581) periods (Chow 305) (Figure 2). The body is round and solid, the right shoulder bare, the rest of the body covered with a garment that has ridges or incised lines, perhaps suggesting pleats. The head is topped with curled 'snail like hair' and the intelligence bump (hair knot?). And the semi-circular face is more characteristic of the Sui Dynasty (Stage 4) than the thinner face of the Longmen style (Stage 2) or the more elongated and oval face of the Tang Dynasty (618-907) style (Stage 5).
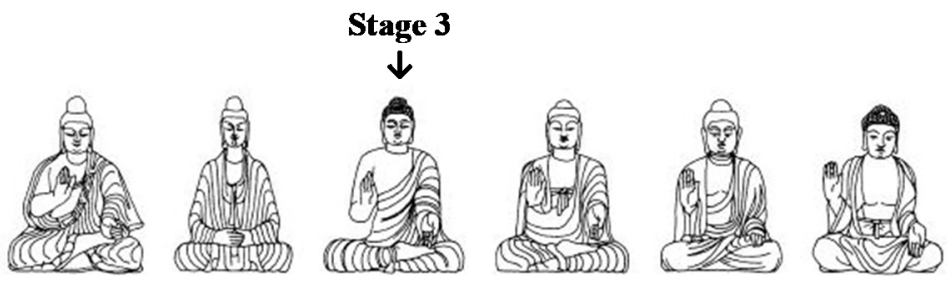

Figure 2. Fong Chow's [Six] Stages of Seated Buddha Sculpture Style (Note 5)

The hands seem to be a less-than-complete variation of the 'Wheel of Dharma' hands often associated with the Buddha Vairocana, which originated in $4^{\text {th }}$ century Kashmir and flourished in early Tang Dynasty (618-907) China (Figure 3). While the halo behind the seated Iron Buddha is in some ways similar to the outer edges of the background halo/mandorla found in a Yungang Buddha stele that goes back as far as the late $5^{\text {th }}$ century and the Northern Wei Dynasty (386-534) (Figure 4).

The back piece below the halo and to the left and right of the main Buddha also highlights two coordinated figures, a common feature in many ancient Buddhist icons. And the foundation seat includes what appears to be a sitting man (woman?), flanked by two animals, supporting or holding up the seated Buddha with his hands and armsvariants of which can be found in other Chinese Buddhist sculpture from the Eastern Wei (534-55) and Northern Qi (550-577) (Figures 5-6) (Note 6). 


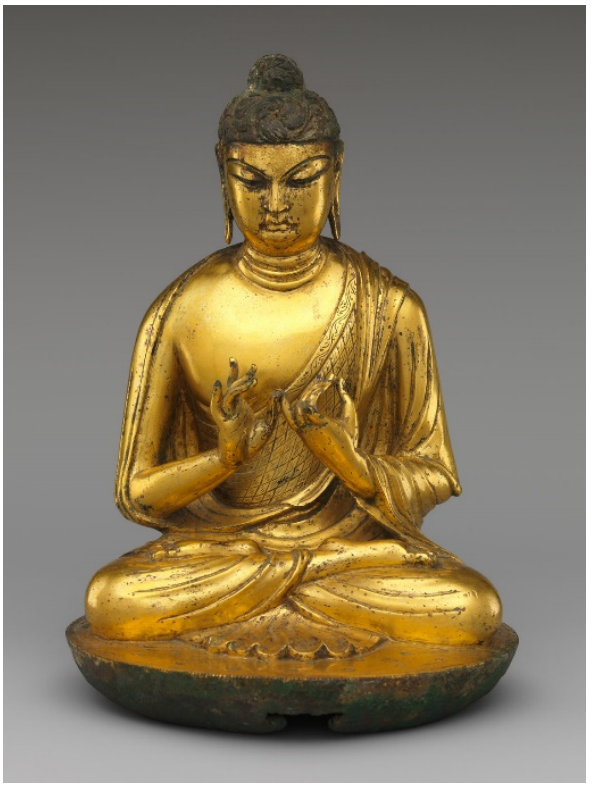

Figure 3. Chinese Buddha Vairocana. $8^{\text {th }}$ cent. Tang. (New York Metropolitan Museum of Art 54080.)

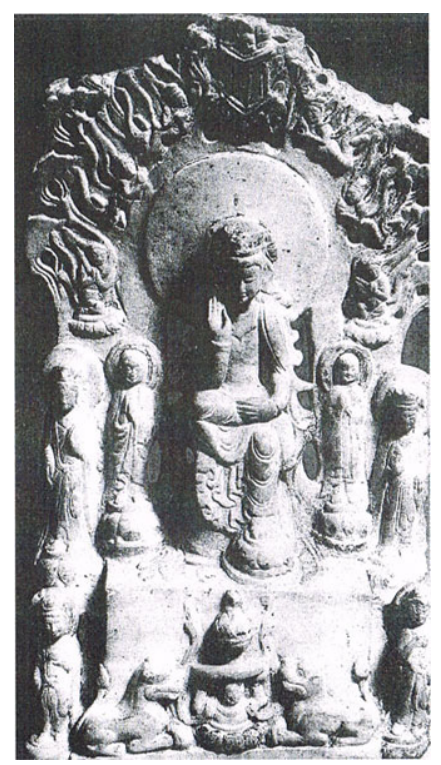

a

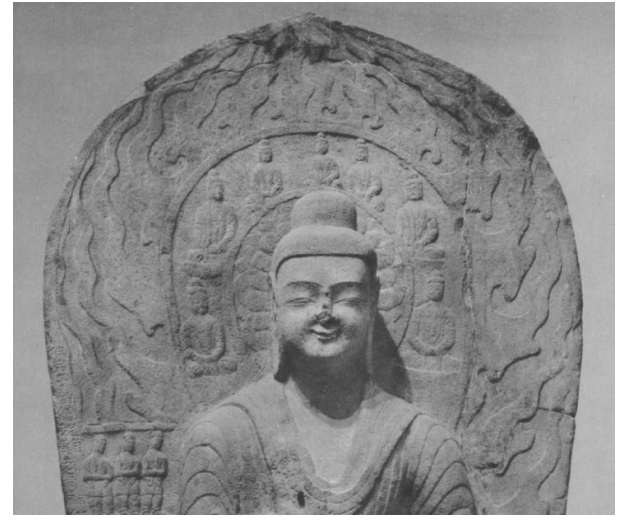

Figure 4. Chinese Buddha Stele. Northern Wei, Yungang Style, 489-495. (New York Metropolitan Museum of Art 65.26.3.)

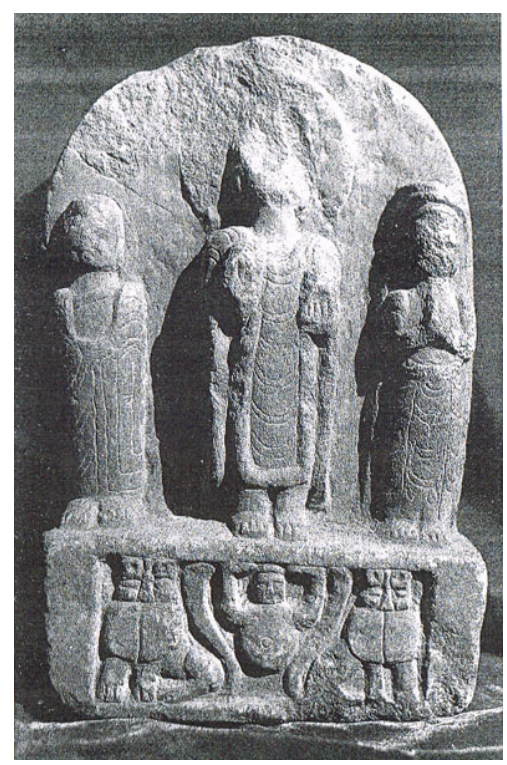

b

Figures 5-6. Chinese Buddhist Icons with Seated Human Support. a. Stone 'Thinking Bodhisattva,' Eastern Wei Dynasty, 544. b. 'Standing Buddha,' Northern Qi Dynasty, 566. (Jin Shen 236, 291.)

\section{Iron Buddha Inscription}

A thirty-one character inscription written in clerical style ( $L i$ shu 隸書) can be found on the back of this Iron Buddha (see Figure 7 and Appendix 4). Confucianism was in decline during the late Northern \& Southern Dynasties and Sui Dynasty periods, knocked from its position of dominance by both Daoism and Buddhism. As a result, many scholars probably turned to Daoist and Buddhist temples to satisfy their needs both for personal development and to make a living. If this piece can be dated to the late $6^{\text {th }}$ century, then one might naturally assume that it was one of those very scholars who authored the Chinese characters used to make this inscription. 
As to whether there is ample evidence to date this piece that far back - all told some 1,400 plus years ago - the content of this inscription suggests a strong affirmative. In fact, after looking closely at the dates mentioned in the inscription, along with the name of the person who appears to have commissioned the Iron Buddha, it is this author's opinion that we can demonstrate this piece did, indeed, originate at the beginning of the Sui Dynasty, and can be classified the Stage 3 Seated Buddha sculpture style mentioned in 2.2 that it seems to fit.

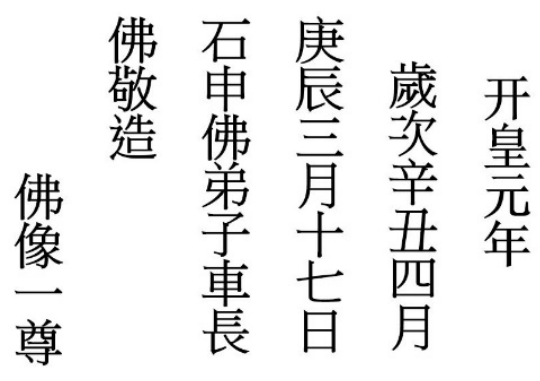

Figure 7. 31-Character Inscription on Back of Iron Buddha (Note 7)

\section{(Translation of Inscription)}

First Year of [the Reign Period] Kai Huang

[Date] The GengChen [first] day of the fourth month in the year XinChou

[581 CE]: On a BingShen day (Note 8), the 17th day of the third month, the Buddhist disciple Ju ZhangFo reverently made

[this] one Buddhist image [sculpture].

\subsection{Dates in Inscription}

Ancient dates, specifically the dates in dynastic calendars, are an area of study in which there exists not a little difference of opinion. Though the dates in this inscription generally correspond with those found in more commonly accepted reconstructions of the early Sui Dynasty calendar, a look at the three separate sexagenary calendar elements in it show there is not complete agreement. Two specific reconstructions of the Sui Dynasty calendar are useful in such a comparison: the Buddhist Studies Authority Database, compiled by the Dharma Drum Buddhist College of Taiwan, and the eminent scholar Chen Yuan's Tables for the First Days of Lunar Months and the Intercalary Months of the Twenty Dynastic Histories [with Appended Western and Muslim Calendars].

The three separate sexagenary elements in the Iron Buddha inscription, following the order they are introduced in the Chinese version of the inscription, are the XinChou year (Note 9), the GengChen $1^{\text {st }}$ day of the fourth month (Note 10), and the BingShen $17^{\text {th }}$ day of the third month. As Appendix 5 shows, the Buddhist Studies Authority Database gives the first year (Note 11) of Sui Dynasty Emperor Wen's reign period, Kai Huang (581-600), as a XinChou year (running from March 6, 581, to February 10, 582, in the Western/Gregorian calendar). And the $1^{\text {st }}$ day of the fourth month of that year is listed as a GengChen day. However, the BingShen day in the third month is listed as the $16^{\text {th }}$, not the $17^{\text {th }}$, with the $17^{\text {th }}$ listed as a DingYou day. According to this reconstructed calendar, then, something is amiss, as the last of the three sexagenary dates in the Iron Buddha inscription does not match up.

Not as easy to read as the Buddhist Studies Authority Database, Chen Yuan's tables equate the first year of the reign of the Sui Dynasty 'Kai Huang' Emperor with the thirteenth year in the reign of the Chen Dynasty (557-581) 'Tai Jian' Emperor (Emperor Xuan, r. 569-581), also a XinChou year (Appendix 6, \#1), which Chen Yuan clearly lists as the year 581 in the Western calendar (Appendix 6,\#2). And the $1^{\text {st }}$ day of the fourth month of that year is given as a GengChen day (Appendix 6, \#3). All of which corresponds exactly with the Buddhist Studies Authority Database. In addition, when counting to calculate what sexagenary date the $17^{\text {th }}$ day of the third month is (Note 12), we can see from Table 1 just below that that day must have been a DingYou day, not a BingShen day. Accordingly, Chen Yuan's tables and the Buddhist Studies Authority Database are in exact agreement, and differ with the Iron Buddha inscription in stating that the BingShen day in the third month is on the $16^{\text {th }}$, not the $17^{\text {th }}$. 
Table 1. Chen Yuan's Reconstruction of the BingShen Day in the $3^{\text {rd }}$ Month of 581

\begin{tabular}{|c|c|c|c|c|c|}
\hline & Month & First Day & Last Day & No. of Days & Special Days \\
\hline \multirow{5}{*}{$3^{\text {rd }}$} & $1^{\mathrm{st}}$ & $\operatorname{Ren} W u$ 壬午 (Note 13) & $\mathrm{XinHai}$ 辛亥 & 30 & NA \\
\hline & $2^{\text {nd }}$ & RenZi 壬子 (Note 14) & GengChen 庚辰 & 29 & $J i a Z i$ 甲子 day, first day of Kai Huang reign period on $13^{\text {th }}$ day of month. \\
\hline & $3^{\text {rd }}$ & $X i n S i$ 辛巳 (Note 15) & GengXu 庚戌 & 30 & BingShen 丙申 day is on the $16^{\text {th }}$ day; $17^{\text {th }}$ day is a DingYou 丁酉 day. \\
\hline & (Intercalary) & $\mathrm{XinHai}$ 辛亥 (Note 16) & JiMao 己卯 & 29 & NA \\
\hline & $4^{\text {th }}$ & GengChen 庚辰 & JiYou 己酉 & 30 & NA \\
\hline
\end{tabular}

The two days of the month found in this inscription clearly had some significance to the person who commissioned the Iron Buddha. If one were to speculate, logic and an understanding of how and why such an icon was made might lead to the assumption that the earlier date, the BingShen day said to correspond with the $17^{\text {th }}$ day of the third month, was the day when the Iron Buddha was commissioned or made, and the latter date, the GengChen day given as the $1^{\text {st }}$ day of the fourth month - all told some forty-three days later (Note 17) — was the day when the Iron Buddha was (to be) dedicated. However, what is the significance of the one-day difference between the day of the month given for the BingShen day in this inscription and that found in the two reconstructed calendars? There are several possible explanations. Perhaps those reconstructed calendars are not correct. Maybe the person who commissioned this Iron Buddha made a mistake when calculating the dates. Or maybe this same person was following another, perhaps now lost, calendar. Which of these possibilities might be closest to the truth starts to become clearer when we look at the name of the person who commissioned the Iron Buddha, and the other areas of interest it opens up.

\subsection{Name of Person in Inscription}

The name of the person who appears to have commissioned the Iron Buddha is given as Ju Zhangfo, the last or family name first, followed by the given name. Ju was a not uncommon family name since ancient times and does not offer much to work with. However, the same cannot be said for the given name, ZhangFo. The first character in this given name (長) was often pronounced zhang (third tone) when used to indicate a person was the eldest son in a family. When pronounced as chang (second tone) it could also have been used to mean "profound" or "permanent." However, a similar name found on another Buddhist piece of sculpture from the same period, a Sui Dynasty Stone Guanyin, suggests that this character, while pronounced zhang (third tone), might have meant something else, perhaps "increase," but more likely something like "uphold" or "advocate"-as in "to uphold/advocate Buddhism" (if we add the second character in the given name, Fo, meaning Buddhism). What suggests a connection between this Sui Dynasty Iron Buddha and the Stone Guanyin is more than just a similarity between names, though. Both pieces also use the exact same three sexagenary calendar dates in their respective inscriptions.

\section{Comparison with Other Figures}

\subsection{Sui Dynasty Stone Guanyin}

The Sui Dynasty Stone Guanyin mentioned in 3.2 is located in the Detroit Institute of Arts (Figure 8). Information on this piece presented in Jin Shen's Chinese-language work Picture-Record of Buddhist Sculpture of Past Dynasties describes it as made of limestone and being 91.4 centimeters ( 36 inches) tall and 28.6 centimeters (11.25 inches) wide (Jin Shen \#227, 516). The Fact Sheet (Note 18) for the Stone Guanyin prepared by the Detroit Institute of Arts adds that it had "traces of gilt and polychrome," and that it was a "Standing male figure dressed in a long gown embellished with jewels...wearing an elaborate crown and raising its right hand in gesture of greeting (or benediction?)." It has an inscription consisting of 83 characters at its base (Figure 9), though Jin Shen gives 84 characters, meaning he thought that one character may have been mistakenly omitted in the original engraving (Jin Shen 516). Both in size/weight and the number of characters in the inscription, the Stone Guanyin is much larger than the Iron Buddha. Unlike the Iron Buddha, the increased number of characters in the inscription makes it relatively easy to ascertain the reason for commissioning this particular piece, with the first half of the inscription up to the fortieth Chinese character following a narrative style that gives two specific dates (Note 19), along with the name of the person who had the piece commissioned, the title of the dedicatee, and the kind of icon created; while the second half is organized into four-character phrases that constitute a prayer-like entreaty for the dedicatee. 


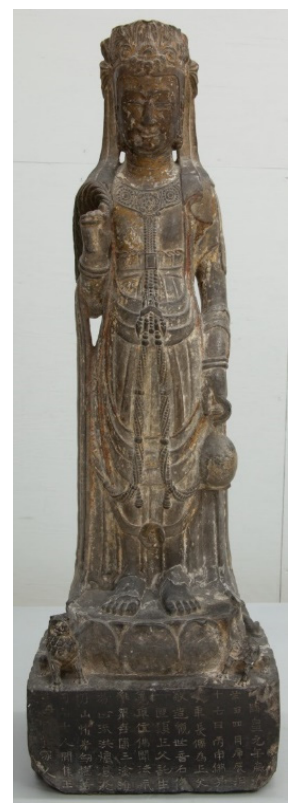

Figure 8. Stone Guanyin. Sui Dynasty, 581. (Detroit Institute of Arts 26.128.) See Appendix 7 for close-up views

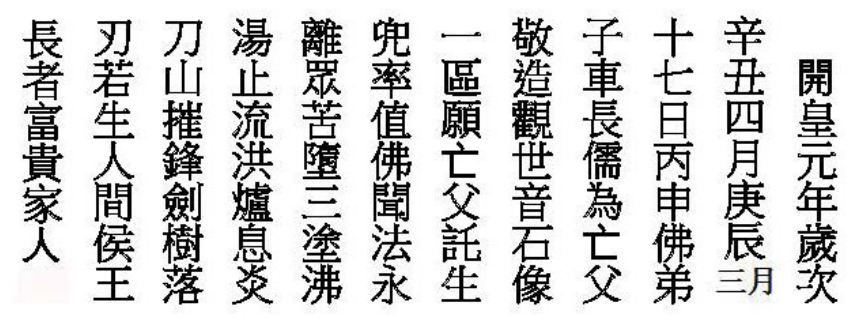

Figure 9. 83-Character Inscription on Stone Guanyin (Note 20)

\section{(Translation of Inscription)}

First Year of [Reign Period] Kai Huang, [Date] the GengChen [first] day of the fourth month in the year XinChou: On a BingShen day, the $17^{\text {th }}$ day of the third month, the Buddhist disciple Ju ZhangRu for [his] deceased (Note 21) Father reverently made [this] one stone GuanShiYin image [sculpture]. [He] wishes that [his] deceased Father consigns his life to the world of Tusita (Note 22), encounters (Note 23) the Buddha and learns the Way, eternally leaving behind the multitude of sufferings and not (Note 24) falling into the Three Roads of Hell (Note 25), [with] the boiling water stopping to flow, the great oven ceasing to blaze (Note 26), and the Knife Mountains having their points broken, the Sword Trees losing their blades (Note 27). If born (reborn?) among humans, [then may he be?] a noble [Marquis or King] elder, a member of a family of wealth and high position (Note 28).

As is apparent from even a cursory reading of this translation, the Stone Guanyin inscription served to commemorate the death of Ju ZhangRu's Father, wishing him well in the next life, be that in one of the Buddhist after-worlds or as a reborn human in this one. However, it also shines some light on three other things that can help us better understand the Iron Buddha.

1) The name Ju ZhangRu is very similar to the Iron Buddha name Ju ZhangFo. Both have the same family name, as well as the same first character for their given names. In addition, the second characters for each given name can be seen as complementary opposites, or at the very least opposing systems of thoughtConfucianism (Note 29) and Buddhism. Assuming, as was done with the name for Ju ZhangFo, that the second character zhang does not mean "elder," but "advocate," would demonstrate a clear parallel structure in the two names based on the meanings of their characters, something very common in the names of siblings from the same family, with Ju ZhangRu's given name then meaning "to advocate Confucianism." Accordingly, even though the use of the character zhang in both names shows that it was not used in Ju ZhangRu's name to indicate he was Ju ZhangFo's elder brother (Note 30), the names still do suggest these two people were brothers (Note 31). Additionally, in the period of disunion in China which followed the fall of the Han Dynasty (206 BCE-220 CE), when Confucianism had declined to be replaced by or at least rivaled by Daoist or rising Buddhist ideas, these names could also be seen as reflective of the changing times.

2) Judging from the difference in size of both the sculptures and their inscriptions, one can assume that Ju ZhangRu, who commissioned the larger Stone Guanyin, was probably the elder brother. He would have taken the lead in the endeavor to honor their deceased Father, and made the larger and more expensive sculpture and offered a clearer and longer explanation of what it was for. The younger brother would have simply 
followed his lead, but not exceeded it. The fact the Father referred to Confucianism in the elder son's name suggests that even during the period of disunion Confucianism was still the more revered Way (at least in the Father's eyes). While the fact both brothers used Buddhism to honor their Father and attempt to help him in his after-life demonstrates the growing power of Buddhism in society at the time.

3) The use of the same three sets of sexagenary characters in the inscriptions from both the Iron Buddha and the Stone Guanyin might lead one to believe that the one-day difference with reconstructed dynastic calendars as concerns the BingShen day of the third month, though not an inadvertent mistake, was perhaps still a mistake, one caused by a common lack of understanding of the calendar the creators of the icons had before them. However, as will be seen below, even that supposition does not seem to fit the facts.

\subsection{Stone Guanyin and Iron Buddha: Significance of Inscription Dates}

Most scholars seem to agree that the Stone Guanyin was indeed a Sui Dynasty work. However, a good number believe the inscription on the Stone Guanyin might not have been. Unfortunately, they simply say it could have been a "later addition" or it "was not original," not really clarifying when it might have been added. Their reasoning, which can be found on the Stone Guanyin Fact Sheet prepared by the Detroit Institute of Arts, follows two main lines. On the one hand is Yutaka Fujioka, professor of art history at Osaka University and specialist in Chinese Buddhist sculpture, who "questioned the authenticity of the inscription on this work because Sui inscriptions typically started on the proper right side." While on the other hand is a group of scholars led by Stanley Abe, associate professor in the Department of Art, Art History, and Visual Studies at Duke University, and specialist on Chinese sculpture. Professor Abe points out that the "inscription begins below the damage on the proper upper left corner...indicating that the inscription is likely not original." Neither of these arguments seems all that convincing.

As concerns Professor Yutaka, it is unclear exactly what data his contention is based on. As Table 2 shows, in looking at 132 works of art found in Jin Shen's Picture-Record of Buddhist Sculpture of Past Dynasties, works which span a 183-year period from 534 to 717, there are numerous examples of inscriptions on pieces of sculpture that clearly begin in or near the proper upper left corner, not the proper upper right-hand corner. Those pieces come from six dynasties, starting with the first year of the Eastern Wei and ending 100 years into the Tang, dating, therefore, from before, during, and after the Sui Dynasty, and suggesting that engraving proper left to proper right was a common practice during this time.

Table 2. Inscriptions Written Starting in Proper Upper Left Corner (Note 32)

\begin{tabular}{|c|c|}
\hline Period/Dynasty & Numbers of Clear Examples in Jin Shen's Work (Note 33) \\
\hline Eastern Wei (534-550) & $\# 155$ (538), \#173 (544). \\
\hline Western Wei (535-557) & \#192 (554). \\
\hline Northern Qi (550-577) & \#191 (553), \#197 (557), \#204 (560), \#218 (570). \\
\hline Northern Zhou (557-581) & \#206 (562), \#214 (567), \#222 (573). \\
\hline Sui Dynasty (581-618) & \#227 (581),\#229 (583),\#231 (583),\#236 (586),\#237 (587), \#240 (593), \#244 (600). \\
\hline [Early] Tang Dynasty (618-907) & $\begin{array}{l}\# 251 \text { (629), \#257 (660), \#258 (663), \#259 (665), \#265 (682), \#267 (689), \#268 (697), \#276 (711), } \\
\# 277 \text { (711), \#279 (717). }\end{array}$ \\
\hline
\end{tabular}

Professor Abe's position is puzzling. Looking at the inscription on the Stone Guanyin, it is obvious that the characters in the proper lower left and proper lower right corners were engraved on this piece before the damage to those parts occurred - which is why parts of the characters in those two places have worn away somewhat. However, what real evidence is there that the first character in the proper upper left corner was engraved on the Stone Guanyin after the damage in that area (Note 34)? Frankly, the indentation of the first character in that area is not all that different from the indentation of the first character on the Iron Buddha. And as unlikely as it may seem, especially in light of the fact that most such frontal inscriptions do indeed seem to fit high up and square in the corners, maybe it was an intentional artistic feature. After all, would an engraver trying to work around any damage in the proper upper left corner really have done it in this manner? Would not a good engraver, working with a sculptor, have found it easy to smooth out most of the damaged imperfections and then centered the Chinese characters on the clean flat surface in such a way as to create a more aesthetically pleasing sculpture with an inscription that fit tightly into the corners - if he so wanted to? And even if we accept Professor Abe's position, who is to say when the damage occurred? Right after the Stone Guanyin was carved, 10-20 years later, or much later? Which leads to the next question: assuming the piece was commemorated on the day in the inscription (Note 35 ), why would someone who was having a piece of sculpture made have the date commemorating it engraved 
after the date it was commemorated? (Note 36) But most important of all, the idea that the Stone Guanyin inscription might have been a later addition seems to overlook some of the evidence in the inscription itself, evidence that appears to date it right around the beginning of the Sui Dynasty. Three things in particular stand out.

1) The thirteenth and fourteenth characters in the Stone Guanyin inscription, the characters translated as "third month," are written together, in one space. It is possible that these two characters were squeezed together because the engraver miscalculated the spacing when engraving the characters, or simply forgot a character, and tried to make up for it in this manner (by going back and adding the character for 3). However, writing two characters together in this manner, something called "combined characters," was a not uncommon practice in earlier forms of writing found on oracle bones, bronze pieces, and steles, similar, perhaps, to writing " 3 months" as "3-months" in English (Note 37), and was not part of any writing convention, but left totally up to the writer/engraver (Note 38). It is less commonly found in writing as late as the Sui Dynasty, can be seen as a continuation of that older tradition (Note 39), and is thus less likely to be something added or used at an even later date.

2) The same general format and some of the phrases in the inscription for the Stone Guanyin can be found in other pieces of Buddhist sculpture from before, after, and during the Sui Dynasty. In fact, when looking at the 132 pieces examined in creating Table 2, one can find the same two parts alluded to in 4.1 in many of the inscriptions: a short, initial, formulaic-narrative description; and a prayer-like entreaty passage that follows this description, a passage whose constituent four-character phrases were very probably part of a store of stock expressions from the era.

Leaving out any explanation of the dates for now, in the Stone Guanyin that initial formulaic-narrative description can be seen as following the pattern given in Figure 10 - using the same or similar terms and expressions as found in other inscriptions from the period (see Tables 3-7).

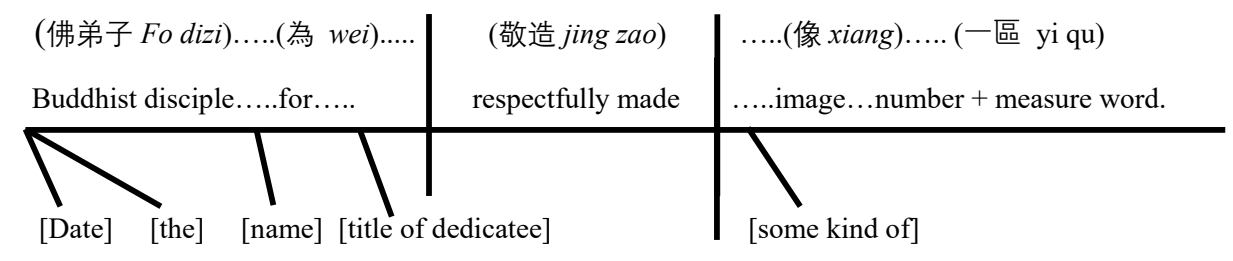

Figure 10. General Structure of Stone Guanyin Inscription

Table 3. Formulaic Narrative-Common (Note 40) Terms for People Commissioning Icons

\begin{tabular}{|c|c|c|c|c|c|c|c|c|}
\hline & East Wei & West Wei & North Qi & North Zhou & Chen & Sui & Tang & Total \\
\hline Disciple 弟子 & 1 & 1 & 1 & & & 1 & 1 & 5 \\
\hline Buddhist Disciple 佛弟子 & 10 & 3 & 5 & 3 & & 5 & 7 & 33 \\
\hline Nun 比丘尼 & 1 & & & & & & 3 & 4 \\
\hline Temple Nun 寺尼 & 1 & & & & & & & 1 \\
\hline Monk 比丘 & 3 & 1 & 4 & 1 & & 1 & & 10 \\
\hline Image Owner 像主/大象主 & & & 4 & & & & 1 & 5 \\
\hline Daoist Believer(?) 道民 & & & & 1 & & 2 & 1 & 4 \\
\hline
\end{tabular}

Table 4. Formulaic Narrative-Use of the Term "For" (Wei) (Note 41)

\begin{tabular}{ccccccccc}
\hline & East Wei & West Wei & North Qi & North Zhou & Chen & Sui & Tang & Total \\
\hline "For" 為 & 13 & 2 & 14 & 2 & & 12 & 12 & 55 \\
\hline
\end{tabular}

Table 5. Formulaic Narrative-Verbs for Making Icons

\begin{tabular}{ccccccccc}
\hline & East Wei & West Wei & North Qi & North Zhou & Chen & Sui & Tang & Total \\
\hline Make 造 & 12 & 3 & 8 & 3 & & 5 & 3 & 34 \\
Respectfully Make 敬造 & 8 & 1 & 10 & 2 & 10 & 14 & 45 \\
Deferentially Make 欽造 & 1 & & & & & & 1 \\
Reverently Make 謹造 & 1 & & & & & & 1 \\
Respectfully Make 敬為 & 1 & & & & & 1 & 1 \\
Respectfully Repair 敬修 & & & & & & & \\
\hline
\end{tabular}


Table 6. Formulaic Narrative-Icon Reference Terms (Note 42)

\begin{tabular}{ccccccccc}
\hline & East Wei & West Wei & North Qi & North Zhou & Chen & Sui & Tang & Total \\
\hline Image 像 & 12 & 3 & 8 & 3 & 5 & 3 & 34 \\
Image 象 & 8 & 1 & 10 & 2 & & 10 & 14 & 45 \\
Image? 相 & 1 & & & & & & & 1 \\
\hline
\end{tabular}

Table 7. Formulaic Narrative-Measure Words for Icons

\begin{tabular}{ccccccccc}
\hline & East Wei & West Wei & North Qi & North Zhou & Chen & Sui & Tang & Total \\
\hline$q u$ 軀 \\
$($ Note 43) & 8 & 1 & 10 & 2 & & 10 & 14 & 45 \\
$q u$ 區 & 12 & 3 & 8 & 3 & & 5 & 3 & 34 \\
$y u / q u$ 傴 & 1 & & & & & & 1 \\
$s h u / q u$ 樞 & & & & & & & 1 \\
$p u$ 鋪 $($ Note 44) & 1 & & & & & & 1 \\
$t a$ 塔 $($ Note 45) & 1 & & & & & & \\
\hline
\end{tabular}

As for the four-character phrases used in the entreaty portion of the Stone Guanyin inscription, there are 44 such characters organized in a very neat, parallel structured 4-4, 4-4, 4-4, 4-4, 4, 4-4 pattern. Table 8 demonstrates that a good number of inscriptions from this period also have either short or longer well-developed four-character groupings, most of which are part of the entreaty, and many of which consist of the same or similar stock expressions (those inscriptions with apparent stock expressions marked in bold).

Table 8. Inscriptions with Four-Character Phrases in Entreaty

\begin{tabular}{|c|c|}
\hline Period/Dynasty & Numbers of Clear Examples in Jin Shen's Work \\
\hline Western Wei (535-557) & $\# 180$ (547), \#187 (551). \\
\hline Northern Qi (550-577) & $\# 184$ (550), \#191 (553), \#194 (555), \#198 (558), \#201 (559), \#217 (570), \#223 (574). \\
\hline Northern Zhou (557-581) & $\# \mathbf{2 0 5}(561), \# 207$ (563), \#211 (565), \#214 (567). \\
\hline Sui Dynasty (581-618) & $\# \mathbf{2 2 8}(581), \# \mathbf{2 3 0}(583), \# 232$ (584), \#234 (585), \#236 (586), \#239 (591), \#240 (593), \#244 (600). \\
\hline
\end{tabular}

Interestingly enough, part of the Sui Dynasty inscription found on \#244 (600) closely resembles part of the entreaty found in the Stone Guanyin: "[He] wishes that the seven generations of [his] parents, and all living things of the Buddhist worlds, eternally depart the Three Roads of Hell, long leave the Eight Difficulties (Note 46), and immediately become Buddhas (Yuan: qishi fumu, fajie zhongsheng, yong qu SanTu, chang ci BaNan, yishi cheng Fo 願：七世父母, 法界衆生, 永去三涂, 長辭八難, 一時成佛 ). It seems, then, that the authors of the inscription for both the Stone Guanyin and the Buddhist Guanyin in \#244 were drawing on a common source of ideas and/or phrases.

Finally, as Table 9 shows, many of these four-character groupings are also directly preceded by the character yuan 願, which signals the beginning of the entreaty - with such a use of this character apparently being more common with pre-Sui Dynasty inscriptions.

Table 9. Inscriptions with Character Yuan Directly Before Four-Character Entreaty Phrases

\begin{tabular}{cl}
\hline Period/Dynasty & \multicolumn{1}{c}{ Numbers of Examples in Jin Shen's Work } \\
\hline Eastern Wei (534-550) & $\# 149(536), \# 153$ (537), \#155 (538), \#156 (539), \#162 (540), \#169 (543), \#172 (544) [?]. \\
Western Wei (535-557) & $\# 180(547)$. \\
Northern Qi (550-577) & $\# 189(552), \# 194(555)$. \\
Northern Zhou (557-581) & $\# 205(561), \# 207(563), \# 214(567), \# 217$ (570). \\
Sui Dynasty (581-618) & $\# 230(583), \# 244(600)$. \\
[Early] Tang Dynasty (618-907) & $\# 258(663)$.
\end{tabular}


3) One could, of course, argue that the data in Tables 2-9 shows the Stone Guanyin inscription, while corresponding in many ways with other Sui Dynasty inscriptions, also matches inscription patterns from the period before the Sui Dynasty - or as Professor Stanley Abe might want to argue, after the Sui Dynasty, perhaps in the Early Tang. But when we turn our attention to the sexagenary dates in the Stone Guanyin inscription, doubts one might still have about dating the Stone Guanyin inscription to the Sui Dynasty may begin to fade somewhat. Because as this author sees it, there seem to be only two ways to explain the oneday discrepancy between the third sexagenary dates found in the Iron Buddha and the Stone Guanyin and those same dates as listed in the Buddhist Studies Authority Database and Chen Yuan's tables—one of which suggests an early Sui Dynasty point of origin.

a. The first theory posits the possibility that the Buddhist Studies Authority Database and Chen Yuan's tables are wrong. Unfortunately, I was able to find only one example where this could be argued, and it was a forced argument at that, one in which some liberty had to be taken in ordering months by assuming that the $17^{\text {th }}$ day of the $3^{\text {rd }}$ month was indeed a BingShen day and then looking for a way in which that would be possible. As Table 10 shows, such a case was possible to make by looking at Chen Yuan's tables, specifically Chen Yuan's sexagenary dates for the first days of months under the Chen Dynasty, some of which run parallel to the Sui Dynasty in his tables. We start by looking at the year 581 of Chen Yuan's "Table on Differences and Similarities in the First Days of Lunar Months and the Intercalary Months of the Chen, Zhou, and Sui," where the shuo day for the first month under the XinChou year (581) is given as RenWu, and the shuo day for the second month is given as XinHai. Then, if we take the third month under the Chen Dynasty (the month listed by Chen Yuan as having a GengXu shuo day) as the intercalary month, not the XinSi month listed as such by Chen Yuan (Appendix 6, \#10), and count forward from the XinHai day to the GengXu day, a total of 59 days (Note 47), keeping in mind that the $17^{\text {th }}$ day of the third month must be a BingShen day, we can see that the second month would have 29 days, and the first day of the 30day third month would be a GengChen day. Continuing on a little more, if the intercalary $3^{\text {rd }}$ month had 29 days, then the first day of the $4^{\text {th }}$ month would be a GengChen day, also corresponding with both the Iron Buddha and the Stone Guanyin (as well as the Buddhist Studies Authority Database and Chen Yuan's tables).

Table 10. Possible Reconstruction Showing BingShen Day on $17^{\text {th }}$ Day of the $3^{\text {rd }}$ Month

\begin{tabular}{|c|c|c|c|c|}
\hline Month & First Day & Last Day & No. of Days & Special Days \\
\hline $1^{\text {st }}$ & RenWu 壬午 (Note 48) & Geng $X u$ 庚戌 & 29 & NA \\
\hline $2^{\text {nd }}$ & XinHai 辛亥 (Note 49) & JiMao 己卯 & 29 & $\begin{array}{l}J i a Z i \text { 甲子 day, first day of Kai Huang reign } \\
\text { period on } 14^{\text {th }} \text { day of month, not the } 13^{\text {th }} \text {. }\end{array}$ \\
\hline $3^{\text {rd }}$ & GengChen 庚辰 & JiYou 己酉 & 30 & BingShen 丙申 day is on the $17^{\text {th }}$ day. \\
\hline $\begin{array}{c}3^{\text {rd }} \\
\text { (Intercalary) }\end{array}$ & GengXu 庚戌 (Note 50) & JiMao 己卯 & 29 & NA \\
\hline $4^{\text {th }}$ & GengChen 庚辰 (Note 51) & WuShen 戊申 & 29 & NA \\
\hline
\end{tabular}

This is indeed a somewhat round-about way of trying to make the $17^{\text {th }}$ day of the third month a BingShen day, and does not even incorporate any specific known dynastic calendar - it does incorporate elements of the Chen Dynasty calendar, though it twists them too much. Actually, as the second theory demonstrates, it is unlikely the Ju Family brothers would have used a Chen Dynasty calendar anyway. Their allegiances seem to have been elsewhere.

b. The second theory assumes that a different calendar was being referenced. Though I have not found any direct evidence to support such a position, as it turns out, when cataloging the dates of many of the Buddhist pieces examined in Tables 2-9, there are a number of sexagenary dates that do not correspond with those in either the Buddhist Studies Authority Database or Chen Yuan's tables - and most of them come from one dynastic period. A look at those dates clarifies the data.

A total of 94 different dates can be found in the 132 pieces looked at in Tables 2-9. Fifty-three of those dates are written using some variant of 'reign year / month / day' without any sexagenary elements (e.g., \#232 [584], Kai Huang sinian qiyue shiwuri 開皇四年七月十五日 “ $4^{\text {th }}$ year of the Reign Period Kai Huang, the seventh month, the $15^{\text {th }}$ day"). The remaining 41 , as Table 11 shows, are written using some variant of 'reign year / month / day,' but with these calendar terms at times being placed in the sexagenary system of dating (e.g., \#153 [537], Tian Ping sinian sanyue BingYin shuo nianbari 天平四年三月丙寅朔廿八日 “ $4^{\text {th }}$ year of the Reign Period Tian Ping, the BingYin first-day third month, the $28^{\text {th }}$ day," [this an example in which a sexagenary element is used only for the first or shuo day of the month]). 
Table 11. Inscription Dates with Sexagenary Elements

\begin{tabular}{|c|c|}
\hline Period/Dynasty & $\begin{array}{l}\text { Calendric Elements Expressed in Sexagenary Form } \\
\text { (Numbers of the Examples in Jin Shen's Work) }\end{array}$ \\
\hline \multirow[t]{8}{*}{ Eastern Wei (534-550) } & Year \\
\hline & $\# 145$ (535) [?], \#147 (536), \#150 (536),\#171 (544), \#172 (544), \#176* (545) [?]. \\
\hline & Month \\
\hline & $\# 153 *(537)[?]$. \\
\hline & Year / Month \\
\hline & $\# 162 *(540)[?]$ \\
\hline & Year / Month / Day \\
\hline & $\# 152$ (537), \#169 (543), \#177 (546). \\
\hline \multirow[t]{6}{*}{ Western Wei (535-557) } & Year \\
\hline & \#158 (539). \\
\hline & Month \\
\hline & $\# 166(542)[?]$ \\
\hline & Year / Month / Day \\
\hline & $\# 187 *(551)$ [?], \#192* (554) [?]. \\
\hline \multirow[t]{6}{*}{ Northern Qi (550-577) } & Year \\
\hline & $\# 201 *(559), \# 212$ (556). \\
\hline & Year / Month \\
\hline & $\# 197 *$ (557), \#198* (558) [?]. \\
\hline & Year / Month / Day \\
\hline & \#189 (552), \#191 (545). \\
\hline \multirow[t]{8}{*}{ Northern Zhou (557-581) } & Year \\
\hline & \#205 (561), \#213 (566). \\
\hline & Month \\
\hline & \#207 (563). \\
\hline & Month / Day \\
\hline & \#206 (562), \#214 (567). \\
\hline & Year / Month / Day \\
\hline & \#211 (565), \#228 (570 [?]. \\
\hline \multirow[t]{6}{*}{ Sui Dynasty (581-618) } & Year \\
\hline & \#231 (583) [?], \#244 (600). \\
\hline & Month \\
\hline & \#237 (587). \\
\hline & Year / Month / Day \\
\hline & $\# 229$ (583), \#230 (583), \#236* (586) [?], \#240 (593) [?]. \\
\hline \multirow[t]{8}{*}{ [Early] Tang Dynasty (618-907) } & Year \\
\hline & $\# 253 *(639)$. \\
\hline & Day \\
\hline & \#266 (686). \\
\hline & Year / Month \\
\hline & \#265 (682), \#271 (705). \\
\hline & Year / Month / Day \\
\hline & \#262 (672), \#276 (711). \\
\hline
\end{tabular}

Not all the inscription dates in Table 11 were easy to decipher due to the poor quality of some of the engravings. There was, then, some guess work involved in reading them, with some characters, as a result, simply omitted in Jin Shen's transcriptions. Those questionable readings are followed by a [?]. In addition, some of the sexagenary dates given are actually wrong, the result of either Jin Shen apparently incorrectly reading the inscriptions or perhaps because of mistakes made in the original engravings by those originally commissioning the pieces. These examples are followed by an asterisk and corrected (Note 52). However, there are four dates (Note 53) which are apparently not the result of mistakes that can be easily corrected, and do not fit into either the Buddhist Studies Authority Database or Chen Yuan's tables. These four dates, which are red bolded in Table 11, all come from the same dynasty, the Northern Zhou (Note 54). Interestingly enough, as Chen Yuan points out (Appendix 6a, \#1) and historical texts have long shown, in 581 it was the Northern Zhou dynasty that handed over its kingdom to the Sui (Sui shu 1.12-13). Is it possible that in the early Sui Dynasty some variation of a dynastic calendar from the Northern Zhou was still being used in places and this is the reason for the discrepancy in the dates of the Stone Guanyin and the Iron Buddha (Note 55)? 
To be sure, it is difficult to make iron-clad conclusions about elements of the above-mentioned four dates in the Northern Zhou Dynasty inscriptions, something necessary to make it easier to believe that a different dynastic calendar that had been used in the Northern Zhou — and into the early years of the Sui Dynasty — was the cause of discrepancies in sexagenary dates in some icon inscriptions when those dates are compared with the dates found in the reconstructed Buddhist Studies Authority Database or Chen Yuan's tables (this different dynastic calendar being the one that the sexagenary dates of the Stone Guanyin and Iron Buddha are based on). However, at the very least these discrepancies stand as clear evidence that the sexagenary dates in the Stone Guanyin and Iron Buddha are not alone in being different from those reconstructed calendars. They also suggest that more work probably needs to be done in looking closer at sexagenary dates in inscriptions and what they tell us about the dates of the icons they are found on (Note 56).

\section{Stone Guanyin and Iron Buddha: Conclusions of Comparison}

The sexagenary dates on the Stone Guanyin hint at an underlying difference with more established or reconstructed dynastic calendars, a difference that may connect its inscription with an earlier, pre-Sui Dynasty calendar (and that period of time). This difference, along with the use of "combined characters" and the general structure of the inscriptions themselves - both the initial, formulaic-narrative description and the prayer-like entreaty passage consisting of four-character phrases that follows - suggests a date for the Stone Guanyin approximating that given in its inscription, namely 581. As it appears the Stone Guanyin and Iron Buddha were created separately by two brothers to honor their deceased Father, it would be only natural to assume both pieces, dated the same, were created at the same time. Of course, the inscriptions on the Iron Buddha and Stone Guanyin are not exactly the same. Though the general structure of the Iron Buddha inscription as seen in Figure 11 is much like the initial, formulaic-narrative description found on the Stone Guanyin (Figure 10), it omits any reference to a dedicatee and the associated prayer-like entreaty passage (Note 57 ).

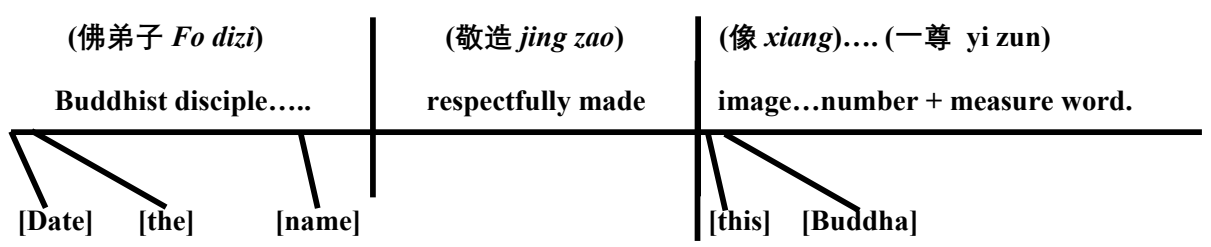

Figure 11. General Structure of Iron Buddha Inscription

In addition, the measure word used for the Iron Buddha, zun, is different. In fact, this measure word was one not found in the inscriptions on any of the other icons listed in Jin Shen's work (see Table 7). Even stranger are the dates found in the inscriptions for both the Stone Guanyin and the Iron Buddha, specifically the use of two dates, the $17^{\text {th }}$ day of the third month and the $1^{\text {st }}$ day of the fourth month (note 58). In the 94 different dates found on the 132 pieces of sculpture from Jin Shen's Picture-Record of Buddhist Sculpture of Past Dynasties that were looked at by this author only one other inscription lists two such dates, and that seems to have been a misreading (Note 59). It is assumed that the earlier of these two dates represents the day the pieces were commissioned, the later date the day they were dedicated, but why all the other pieces of sculpture this author looked at failed to be so exact is puzzling. Apparently, it was simply not a common practice to list both dates when writing inscriptions, though some might want to suggest that not listing both dates would be only commonsensical. After all, could one know for certain when commissioning an icon exactly when it would be dedicated (Note 60)? Which would then perhaps even lead them to speculate that this proves the inscription on the Stone Guanyin was engraved on that piece after it was dedicated. But can the same be said of the Iron Buddha? As the inscription was put on the Iron Buddha when it was created, following the same logic, that would be possible only if one assumed the Iron Buddha was commissioned and created after it was dedicated, and that does not make sense.

\section{The Final Word on the Iron Buddha}

Questions remain, for sure, about the origins and nature of the Iron Buddha, as one might expect with any piece of old sculpture. Nevertheless, there seems to be more than enough evidence to conclude the Iron Buddha was, in fact, a product of the early Sui Dynasty, evidence that includes its Stage 3 style, the specific features that define it, and the content of its inscription. All of which make it a rare piece, indeed, because as such it stands as a reminder of a larger story, one that was being played out during the Northern \& Southern Dynasties period, when Chinese social order and the Confucian ideology supporting it declined, to be replaced in many areas by the growing 
influence of Daoism and Buddhism. Within such a transformation, in fact reflective of the new dynamic, we are able to discover the tale of two filial sons, still following the centuries-long Confucian tradition of honoring their deceased Father, but doing so now within the context of a Buddhist worldview, one in which they also wish him freedom from pain and re-birth in a better place.

\section{Acknowledgements}

Special thanks to Tsai-fa Cheng (鄭再發), Professor Emeritus of the University of Wisconsin - Madison and a life-long mentor, for his invaluable insights into the manufacturing process of the Iron Buddha as well as the problem of dating the inscription. The author alone is responsible for any errors or inaccuracies in translations or interpretations.

\section{References}

Chen, Y. 陈垣 (1880-1971) (1926). Tables for the First Day of Lunar Months and the Intercalary Months of the Twenty Dynastic Histories [with Appended Western and Muslim Calendars](Ershi shi shuo run biao: Fu Xili Huili二十史朔闰表：附西历回历). Beijing: Li yun Books. Specific pages include the following: Tables for the First Days of Lunar Months and the Intercalary Months of the Twenty Dynastic Histories, 80; Table on Differences and Similarities in the First Days of Lunar Months and the Intercalary Months of the Chen, Zhou, and Sui (Chen Zhou Sui shuo run yitong biao 陳周隋朔潤異同表), 222.

Chow, F. (1965). Chinese Buddhist Sculpture. The Metropolitan Museum of Art Bulletin, 301-325.

Detroit Institute of Arts. (n.d.) Sui Dynasty Stone Guanyin Fact Sheet. Single page document. Appendix 8.

Detroit Institute of Arts. Sui Dynasty Stone Guanyin photo. 26.128. See Appendix 8.

Dharma Drum Buddhist College of Taiwan. (2017). Buddhist Studies Authority Database (Foxue guifan ziliaoku 佛學規範資料庫). Retrieved from http://authority.ddbc.edu.tw/, with relevant materials located in Time Authority Data Base (Shijian guifan ziliaoku 時間規範資料庫) under the Sui Dynasty.

Fendos, P. (2016). Chinese Iron Buddha photos. Jpegs. Figure 1, and Appendices 1, 2, and 3-4.

International Chemical Analysis. (2016). E-mail report. Web Site for this radio-carbon dating lab can be found at http://radiocarbon-dating.com/

Jin, S. 金申. (1994). Picture-Record of Buddhist Sculpture of Past Dynasties (Zhongguo lidai jinian Foxiang tudian 中國歴代纪年佛像圖典). Beijing: Wenwu Publishing.

New York Metropolitan Museum of Art. (n.d.). Chinese Buddha Stele. Online photo \#65.26.3. Retrieved from http://www.metmuseum.org/ toah/works-of-art/65.29.3/ .

New York Metropolitan Museum of Art. (n.d.). Chinese Buddha Vairocana. Online photo \#54080. Retrieved from http://www.metmuseum.org/collection/the-collection-online/search/54080

Sui shu 随書 (Sui Dynastic History). (1983). In J. L. Yang 陽家駱 (Ed.), Taiwan version (Xin jiaoben Sui shu 新校本隋書) (Zhonghua shuju 中華書局 ed.). Taibei: Dingwen Book Store.

\section{Notes}

Note 1. The Jin Ancestral Temple is about 25 kilometers southwest of Taiyuan City (Shanxi Province), about halfway between the two largest Buddhist grottoes in northern China, the Yungang Grottoes near Datong and the Longmen Grottoes near Luoyang, and just a short drive from the Longshan Grottoes and Hanging Temple.

Note 2 . The contamination was found in the graphite extracted from the iron in the early stages of the radio-carbon dating process.

Note 3. The three pieces, including the Chinese inscription on the back, were probably made using a multi-step process: 1) carving clay or wood positive molds; 2) converting those positive molds into clay negative molds; and 3 ) using those negative molds to cast the iron pieces. Once completed the three pieces were then joined using some kind of forging technique.

Note 4. Especially the area where the Buddha connects to the back piece, though that may also simply reflect poor forging technique.

Note 5. The six stages of the Seated Buddha represented in Figure 2 are, from left to right, the Yungang, Longmen, Northern Qi and Northern Zhou, Sui, Tang, and Song.

Note 6. At least three examples of this kind of sculpture can be found in Jin Shen's Picture-Record of Buddhist Sculpture of Past Dynasties: \#170, \#171, and \#212. The two in Figures 5-6 are \#170 on the left and \#212 on the right. 
Note 7. Translated by author. Note that the sexagenary system (Jiazi 甲子) combinations of Heavenly Stems (Tiangan 天干) and Earthly Branches (Dizhi 地支) are used when referring to both the one year and the two days of the month in this inscription (three elements in total). The months are simply referred to using the corresponding 29/30-day periods in the ancient Chinese lunar calendar, i.e., $3^{\text {rd }}$ month and $4^{\text {th }}$ month. One day, the one that is not a 'first day of the month' (see n. 10 just below), is also referred to with numbers.

Note 8. Reading shi/石 as a broken character (po zi 破字) for bing/丙.

Note 9. The general term for “year" within the Chinese sexagenary system of time/dates being sui ci 歲次.

Note 10. Months in these sexagenary calendars are also usually referred to by this “first" or shuo 朔 day, a term which actually refers to the first day of the moon in 29/30-day lunar months (though that character shuo is not used in the Iron Buddha inscription). The phrase in the Iron Buddha inscription 四月庚辰 siyue GengChen could, then, perhaps be understood two ways: "GengChen [first] day of the fourth month" or "GengChen [first]day fourth month."

Note 11. Designated using the characters yuan nian 元年.

Note 12 . Done by using a diagram like the one below, locating the first days of any month in the sexagenary system and counting ahead.

\begin{tabular}{|c|c|c|c|c|c|c|c|c|c|}
\hline 甲子 & 乙丑 & 丙富 & 丁知 & 戊展 & 己ᄅ & 康午 & 辛未 & 壬申 & 発西 \\
\hline 1 & 2 & 3 & 4 & 5 & 6 & $?$ & 8 & 9 & 10 \\
\hline 甲成 & 乙詃 & 丙子 & 丁耳丑 & 戊豈 & 己卯 & 庚辰 & 辛巳 & 壬午 & 癸未 \\
\hline 11 & 12 & 13 & 14 & 15 & 16 & 13 & 18 & 19 & 20 \\
\hline 甲申 & 乙酉 & 丙戌 & 丁亥 & 戊子 & 己丑 & 厷富 & 辛卯 & 王辰 & 癸已 \\
\hline 21 & 22 & 23 & 24 & 25 & 26 & 23 & 28 & 29 & 30 \\
\hline 甲午 & 乙未 & 丙申 & 丁西 & 此戌 & 已可 & 庸子 & 辛丑 & 王耍 & מ \\
\hline 31 & 32 & 33 & 34 & 35 & 36 & 37 & 38 & 39 & 40 \\
\hline 甲辰 & ze & 丙午 & 丁未未丷 & 戊申 & 己酉 & 康成 & 辛永 & 壬子 & 㓌丑 \\
\hline 41 & 42 & 43 & 44 & 45 & 46 & 43 & 48 & 49 & 50 \\
\hline 甲画 & 乙卯 & 丙辰 & Te & 戊午 & 己未 & 庚申 & 辛酉 & 壬成 & 癸永 \\
\hline 51 & 52 & 53 & 54 & 55 & 56 & 53 & 58 & 59 & 60 \\
\hline
\end{tabular}

Take an example as seen in Table 1: in the third month, from and including the first day XinSi (\# 18) to BingShen (\#33) is sixteen days (not seventeen).

Note 13. See Appendix 6, \#4.

Note 14. See Appendix 6, \#5.

Note 15. See Appendix 6, \#6.

Note 16. See Appendix 6, \#7. The intercalary third month follows the normal third month.

Note 17. Forty-three days later and not fourteen because of the addition of a twenty-nine-day intercalary month after the third month. Or forty-four days, if we accept the BingShen day being on the $16^{\text {th }}$ day of the third month. Either way, there was plenty of time to finish the sculpture before the set dedication date.

Note 18. Forwarded to this author by the Asian Curator of the Detroit Institute of Arts, Dr. Birgitta Augustin. See Appendix 8.

Note 19. The same two dates as found on the Iron Buddha-the $1^{\text {st }}$ day of the fourth month and the $17^{\text {th }}$ day of the third month, both in the first year of the Reign Period Kai Huang - with the dates written in almost exactly the same way as on the Iron Buddha.

Note 20. Translated by author.

Note 21. Jin Shen gives the character before $f u$ 父 as shang 上 (Jin Shen 516). However, I could find no examples of the binome shangfu in ancient texts and read these two characters as wangfu 亡父 , "deceased Father." Within the context of the inscription it seems much more appropriate. Actually, in many other parts of his book, Jin also reads the same character as "deceased." It is unclear why he did not do so in this case. It appears to be a typo.

Note 22. A transliteration of a Sanskrit term referring to one of six Buddhist deva-worlds where all Bodhisattvas destined to reach enlightenment in their next life dwell, and a place thought reachable through meditation.

Note 23. Translating zhi 值 as "encounter" or "meet," zhiyu 值遇.

Note 24. Jin Shen's rendering of this inscription includes the character $b u$ 不 before the character $z h u i$ 墮一 something not found in the original inscription (Jin Shen 516). Within the context of the inscription, and the series 
of four-character phrases in this part of it, it is a logical addition, suggesting that it may indeed have inadvertently been omitted when the engraving was carried out.

Note 25. The Three (Buddhist) Roads of Hell being Fire, Knives, and Blood—where people suffer for past transgressions.

Note 26. The boiling water and burning oven also obviously being sources of suffering.

Note 27. The terms 'Knife Mountains' and 'Sword Trees' refer to two of the 16 (?) Buddhist hells in which people suffer after death. The former is a place surrounded on all sides by mountains that are covered in untold myriads of knives; the latter a place where swords stand erect like forests of trees. In both places people would suffer from the knives and swords when simply moving around, and wishing that the points of the knives broke and the blades of the swords fell off would apparently be one way of hoping that the suffering in those places was ameliorated.

Note 28. Reading the first two characters in each of the last two four-character phrases as descriptive terms.

Note 29. The character $r u$ 儒, then, read as "Confucianism," not "learned," or even "weak," other denoted meanings.

Note 30. Or vice-versa.

Note 31. These are masculine and not feminine names.

Note 32. The author has referenced the transcriptions of all inscriptions found at the end of Jin Shen's book, and uses them throughout this paper. However, only those pieces whose inscriptions are readable in the icon photographs supplied in Jin Shen's work are used in this table. There no doubt will be others that begin in the proper upper left corner, but the author cannot ascertain that to be so without closely looking at the sculptures themselves, or larger and easier to read copies of the inscriptions on them than those provided by Jin Shen. Accordingly, the data provided in this table should not be seen as exact or complete, but approximate, and reflective only of tendencies or patterns. Actually, even when working with the transcriptions of inscriptions, as is done in Tables 3-9 and 11, the author aims only at tendencies or patterns and does not claim to offer exact or complete numbers.

Note 33. Numbers given after the \# sign correspond to the numbers of the photographs in Jin Shen's work. The numbers within the parentheses refer to the year given in the relevant inscription.

Note 34. The damage includes not just the proper upper left flat surface, but the animal above it, which has been broken off. And though I cannot be certain unless I look at the sculpture itself, at least a small part of the damage in this area, that done to the first character kai 開, along with damage done to other characters at the top of the inscription, seems to have occurred after the inscription was engraved.

Note 35. Meaning, as is the case with the Iron Buddha, that the BingShen day said to correspond with the $17^{\text {th }}$ day of the third month was the day when the Stone Guanyin was commissioned - and the GengChen day given as the $1^{\text {st }}$ day of the fourth month was the day when the Stone Guanyin was dedicated (the anniversary of the death of the Father?).

Note 36. Actually, it seems that when later additions or repairs are made to a piece or its inscription, a point is made to mention that in the inscription. Note, for example, \#228 (581), \#234 (585), and \#262 (672) in Jin Shen's work. So, one wonders why, if the inscription really was added at a later date, the inscription did not say so. And even if one still wanted to argue Abe was correct and the inscription was added later, I would again have to counter by arguing that it would only make sense for whoever did add it to have at least cleaned up the flat surface so a more aesthetically pleasing inscription could be created (one in which the inscription was tight in the corner, and not indented, if that was the more desirable end result).

Note 37. The Chinese term for "combined characters" being hewen 合文. In addition to months, examples frequently found in ancient writings include ancestor names and types of sacrifices. Some characters were combined side-by-side, some, one right above the other, with most such combinations consisting of two characters, but some also three.

Note 38. To paraphrase Professor Cheng Tsai-fa, who introduced the concept of combined characters to me.

Note 39. The conclusion of some discussions on this inscription with Professor Cheng Tsai-fa.

Note 40. Though not a complete list.

Note 41. The most common pattern is "X for Y made Z," where $\mathrm{Y}$ is the person for whom the icon was made. However, another not uncommon pattern is " $\mathrm{X}$ made $\mathrm{Z}$, for $\mathrm{Y}$," with the $\mathrm{Y}$ sometimes representing two levels of at times multiple recipients: e.g., "for YY above" (shang wei 上為 YY...) and "for YY below" (xia wei 下為 YY...). 
Note 42. The term xiang 象was used to mean image as early as the Book of Changes, though in that text it usually referred to the image of a trigram or hexagram. It was also a common phonetic borrowing for xiang 像, meaning "resemblance" or "image," in the sense of 'an image of the Buddha,' which is how it seems to be used in these inscriptions. Xiang 相 also seems to be another such borrowing.

Note 43. The basic meaning of this character is "body" or "trunk," with the character itself consisting of two parts: the semantic element shen 身, meaning "body," and the phonetic element $q u$ 區. Three other characters used as measure words also have this same phonetic element: the character $q u$ 區 alone; the character $y u$ 傴, originally having meant "hunchback, " but later also "respectful” or "reverent;" and shu 樞, or "hinge/pivot." I am assuming that all three of these characters were simply borrowings pronounced $q u$ and meant "body" or "trunk." They were used in this way, then, to refer to the Buddhist icon in the respective sculptures. The character $y u$ may have been so adopted because it has the radical for "person," ren 人, as its semantic element. The same cannot be said for, $s h u$, the character that originally meant "hinge/pivot," as that character has the radical for "wood," $m u$ 木 as its semantic element, but the piece it is used to count is made of stone. It seems to simply be a borrowing.

Note 44. It is unclear to this author why this character is used as a counter for a piece of Buddhist sculpture. Pu was used in reference to door decorations, usually, it seems, ring-type door decorations, but the pieces it is used with in Jin Shen's work (\#257, \#260, \#263, \#270, and \#276), all apparently carved from stone, are of two different types--standing plaque-like Buddhas and sitting Buddhas.

Note 45 . The character $t a$ was used to refer to a stupa or Buddhist sanctuary, so why it is used with $\# 259$, a sitting Buddha, is again unclear to this author.

Note 46. Similar phrase also seen in \#155 (Jin Shen 538).

Note 47. Again, an intercalary month would follow the regular month.

Note 48. See Appendix 6, \#4.

Note 49. See Appendix 6, \#8.

Note 50. See Appendix 6, \#9.

Note 51. See Appendix 6, \#3.

Note 52. I found ten such examples and give short explanations of them here, with corrections based on the Buddhist Studies Authority Database and Chen Yuan's tables. (1) \#153 (537), 天平四年三月丙寅朔廿八日: the third month is actually a 丙申 BingShen month and the fourth month a 丙寅 BingYin month, so either the sexagenary shuo elements were read wrong or the month should have been engraved as a fourth month. (2) \#162 (540), 維大魏興和 二年歲【次】申三月甲 【?】廿三日: the character [次 $c i$ ] should probably have been read as 庚 geng as 庚申 GengShen is the sexagenary date for this year; it is unclear what sexagenary shuo element goes in [?], as the shuo day for the third month is actually 己酉 JiYou and the only other shuo days in this year that use 甲 are甲戌 JiaXu, for the eleventh month, and 甲辰 JiaChen, for the twelfth month; this shuo sexagenary date is perplexing and I cannot know if it is the result of a misreading by Jin Shen, a mistake by the person who commissioned the piece, or based on a different calendar. (3) \#176 (545), 武定三年歲在乙丑四月丁丑朔十五日: the 丁丑 DingChou month is actually the ninth month, so I am guessing 九 jiu was incorrectly read as 四 si. (4) \#187(551), 大统十七年歲 次辛未三月乙巳朔 【?】五月己未: the second 月 yue character should probably read as 日 ri or "day," with the character in [?] then becoming + shi or "ten," as the $15^{\text {th }}$ day of the third month is a 己未 JiWei day. (5) \#192 (554), 唯大魏元年歲次甲戌四月丁亥朔十二日庚辰: the shuo day for the fourth month is 丙辰 BingChen, the shuo day for the third month 丁亥 DingHai, and as the sexagenary shuo elements are not similar, I am guessing that the month was either read or engraved incorrectly and should read as the third month; no sense can be made of the sexagenary element for the day of the month, as there is no 庚辰 GengChen day in the third month and the $12^{\text {th }}$ day of the third month is a 戊戌 $W u X u$ day, while the $12^{\text {th }}$ day of the fourth month is a 丁卯 DingMao day and the only 庚辰 GengChen day in the fourth month is on the $25^{\text {th }}$. Either these dates were calculated incorrectly or perhaps based on a different calendar. (6) \#197 (557), 大齊天保八年歲次丁丑四月乙巳朔八日: 乙 $y i$ should read as 己 $j i$. (7) \# 198 (558), 大齊天保九年太歲在寅九月辛卯朔廿 九日: the character 在 $z a i$ should read as 戊 $w u .(8)$ \#201 (559), 惟大齊天保十年歲次巳卯二月十五日: 巳 si should read as 己 ji. (9) \#236 (586), 開皇六年歲在 丙午六日庚辰朔八日丁亥: the first 日 $r i$ should read as 月 yue. (10) \#253 (639), 貞觀十三年歲次巳亥五月二 十五日: 已 $s i$ should read as 己 $j i$.

Note 53. (1) \#206 (562) 保定二年四月辛未朔八日戊寅: the shuo sexagenary element for the fourth month is actually 庚子 GengZi; 辛未 XinWei is the shuo sexagenary element for the first month intercalary month; in the GengZi month there is no 戊寅Wuyin day, instead, the 8th day of that month is a丁未 DingWei day; but in the XinWei month the $8^{\text {th }}$ day is a WuYin day. The inscription is clear enough to read. Was the month engraved 
incorrectly, was there a mistake done when originally calculating these sexagenary dates, or was a different calendar being used? (2) \#207 (563) 保定三年六月甲午朔: the shuo day of the sixth month is a 癸巳 GuiSi day; 甲戈 $J i a W u$ is the shuo day of the fourth month; this author was not able to read the date on this piece, but the characters for 6 and 4 are different enough, so assuming that 6 is what the inscription reads, was the shuo element for the sixth month engraved incorrectly, was there a mistake done when originally calculating these sexagenary dates, or was a different calendar being used? (3) \#211 (565) 保定五年歲次乙酉九月辛亥朔七日丁巳: 乙酉 YiYou is the correct shuo element for the year; the shuo day for the ninth month, however, is 庚辰 GengChen, with 辛亥XinHai being the shuo element for the eighth month; there is no 丁巳 DingSi day in the ninth month, though DingSi is the sexagenary element for the $7^{\text {th }}$ day in the eight month; this author was not able to read the date on this piece, but assuming it is correct, the characters for 9 and 8 seem different enough, so was the character for 9 engraved by mistake, was there a mistake done when originally calculating these sexagenary dates, or was a different calendar being used? (4) \#214 (567) 天和二年三月丙申一十四日庚子: the sexagenary element for the shuo day of the third month is 任申RenShen, there is no month with a 丙申 BingShen shuo day; the $14^{\text {th }}$ day of the RenShen month is 乙酉 YiYou, but the $29^{\text {th }}$ day is a 庚子 GengZi day; this author was not able to read the date on the icon directly, though the characters that he did see were neat and clean; but should the characters for " $14^{\text {th }}$ day" read " $29^{\text {th }}$ day" and the characters for BingShen read RenShen, and was there a mistake done when originally calculating these sexagenary dates, or was a different calendar used?

Note 54. The dates for two other inscriptions, both found in n. 52, [(2) \#162 (540) and (5) \#192 (554)], also have month and day sexagenary elements respectively that cannot be reconciled easily with either the Buddhist Studies Authority Database or Chen Yuan's tables. However, these dates have other problems that were solved, problems that seem to have resulted from incorrect readings due to the poor quality of the inscriptions, so they are not included here (though I still wonder if perhaps they too were incorrectly calculated or based on a different calendar) Perhaps, then, at least parts of some of the four Northern Zhou inscription dates might also be so solved, assuming they are also based on incorrect readings due to the poor quality of the inscriptions (again, author has been able only to work with Jin Shen's book, and not directly read all of these inscriptions on the associated pieces), though I conjecture not.

Note 55. As is pointed out in $\mathrm{n} .56$ just below, it is generally acknowledged that the Daxiang $l i$ calendar used during the last two years of the Northern Zhou was used during the first two years of the Sui Dynasty, before the Sui Kai Huang $l i$ 開皇歷 calendar was inaugurated in 584, but this author is unsure if that alone can explain sexagenary date differences.

There are, of course, other problems with this theory than those pointed out in notes 52 and 53. Any such theory would need to apply to all—or at least a great number—of the sexagenary dates used during the Northern Zhou. However, the sexagenary dates in the inscriptions for Jin Shen icons \# 205 (561) and \#213 (566), also from the Northern Zhou but matched only with the years in those inscriptions, correspond with the reconstructed dynastic calendars. Would that perhaps suggest any differences would be found only with the sexagenary elements attached to shuo days and the other days of the month? In addition, the sexagenary elements found on the inscription for \#228 (570) correspond at the year, month, and day level. Strangely, though, part of that inscription details repairs made to the icon in 587 . Could that mean the sexagenary dates attributed to the year 570 were really engraved in 587, when the Sui Dynasty calendar had been corrected to excise any old Northern Zhou influences?

Note 56. The best way to do this might be to go back and look at the calendars used at this time, in particular the 天和歷 Tianho li, used in the Northern Zhou from 566-578, and the 大象歷 Daxiang li, used in the Northern Zhou from 579-581 and the Sui Dynasty from 581-583-maybe even the 正光歷 Zhengguang li, used in the Northern Zhou from 557-565. The Zhengguang li was also used in the Eastern Wei from 534-539 and the Western Wei from 535-557, the time periods from which the two inscriptions pointed out in $\mathrm{n} .54$ also originated. These may just be coincidences, but the idea that elements of earlier (or even local variant) calendric systems different from reconstructed dynastic calendars could have been used in ancient icon inscriptions seems only commonsensical...though going back and looking at these different ancient calendric systems is not something this author is presently prepared to do.

Note 57 . Then, again, the shorter inscription may simply have been due to the younger brother trying not to outdo his elder brother (as concerns the size of the sculpture, which would have limited the number of characters he could use).

Note 58. The dates are in separate months, the shuo date of the fourth month also apparently referring to that first day of the month (not just used in helping identify the fourth month i.e., as the GengChen first day fourth month- 
though one might argue that the two pieces could have been commemorated anytime during the GengChen fourth month).

Note 59. See n. 52, \#4, where it is pointed out that one of the characters for "month" should be changed to the character for "day." Not making this change would result in the inscription having two shuo days (in two different months). Of course, n. 36 also makes reference to inscriptions that mention repairs/changes/additions made to three icons and their inscriptions [\#228 (581), \#234 (585), and \#262 (672)], with parts of the new inscriptions then including the new dates when these repairs/changes/additions were made, but that is different from the two dates on the Iron Buddha and Stone Guanyin, which are part of the original inscription.

Note 60. Unless one had a particular date in mind - such as the anniversary of someone's death?

\section{Appendix}

Appendix 1. Iron Buddha Front View (Fendos, 2016)

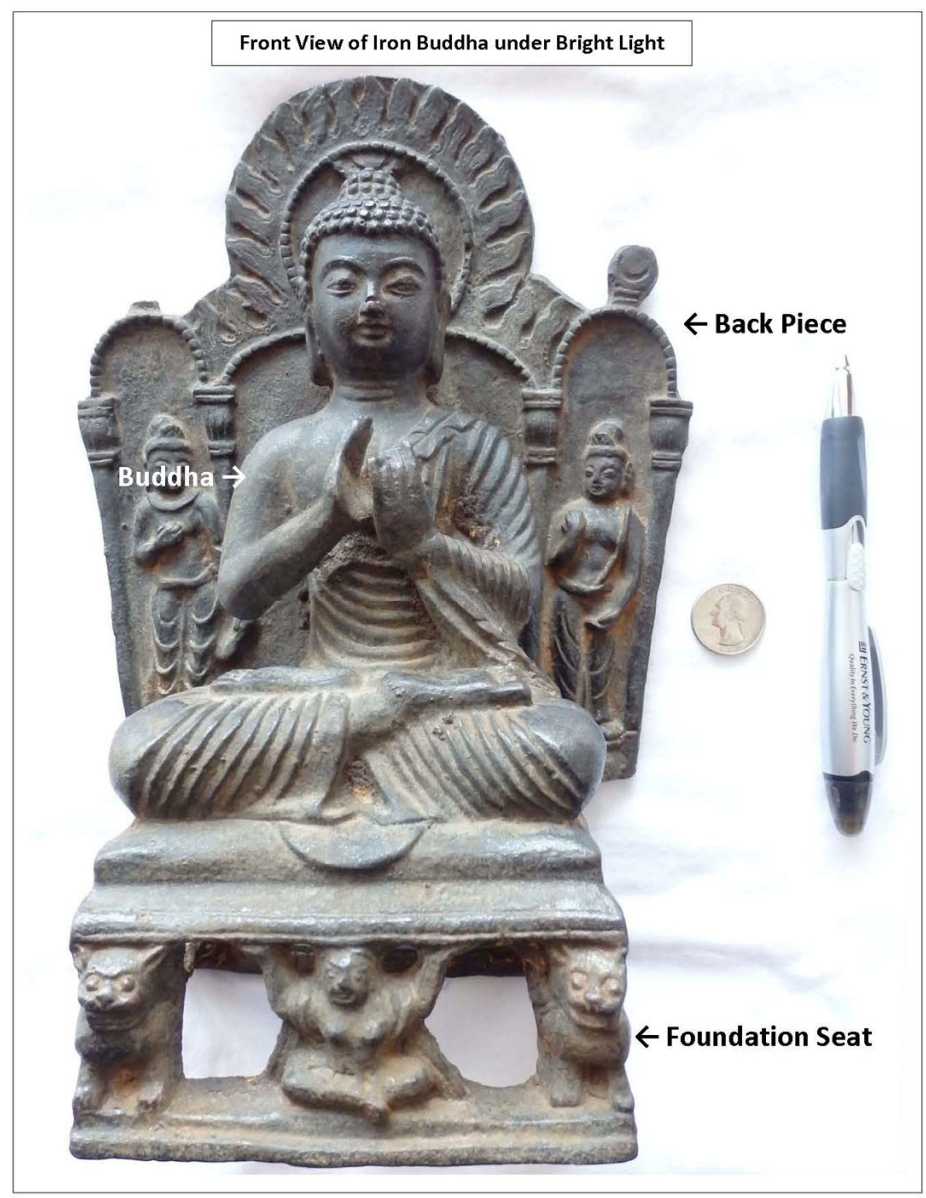


Appendix 2. Iron Buddha Side View (Fendos, 2016)

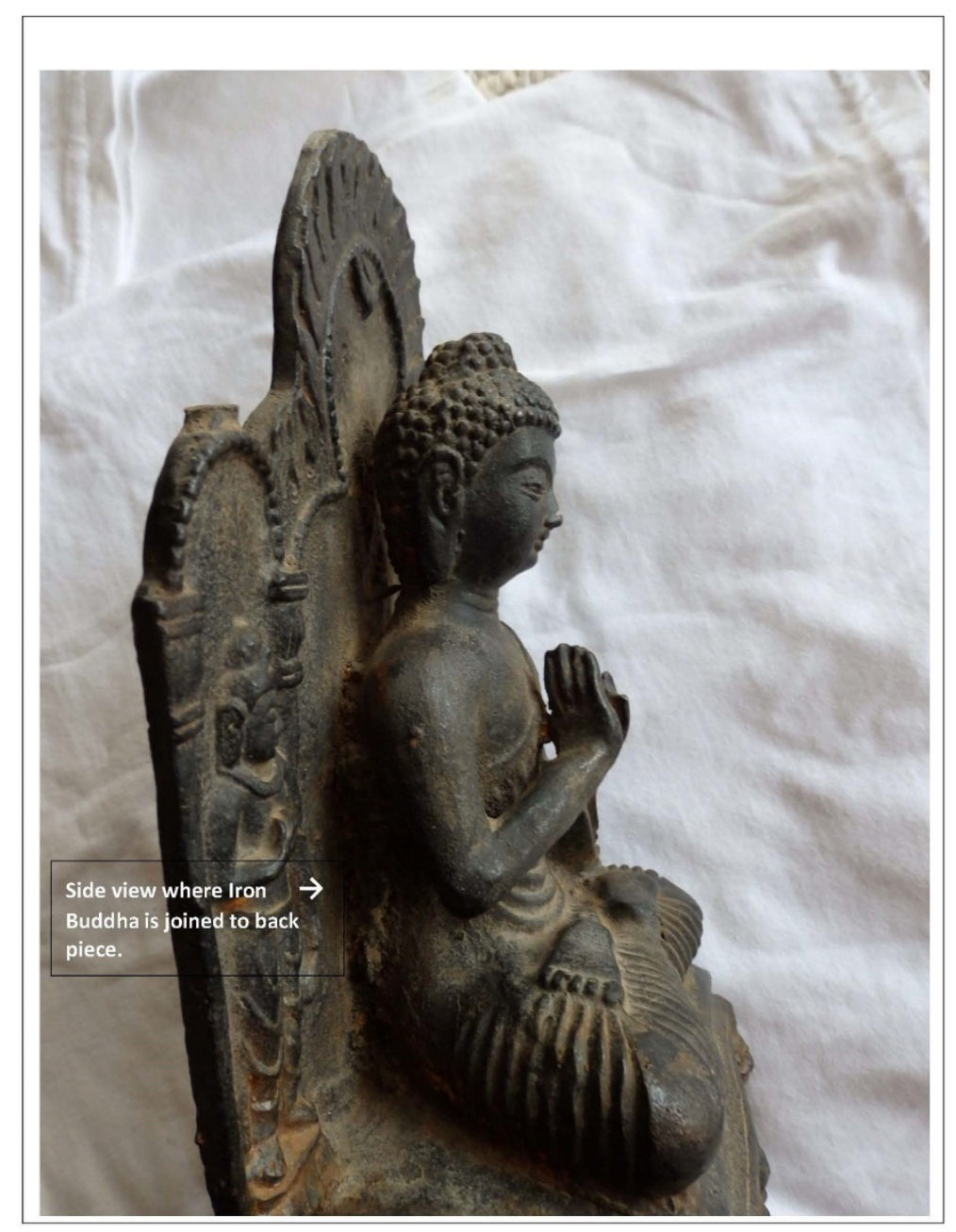

Appendices 3-4. Iron Buddha Inside \& Back Views (Fendos, 2016)
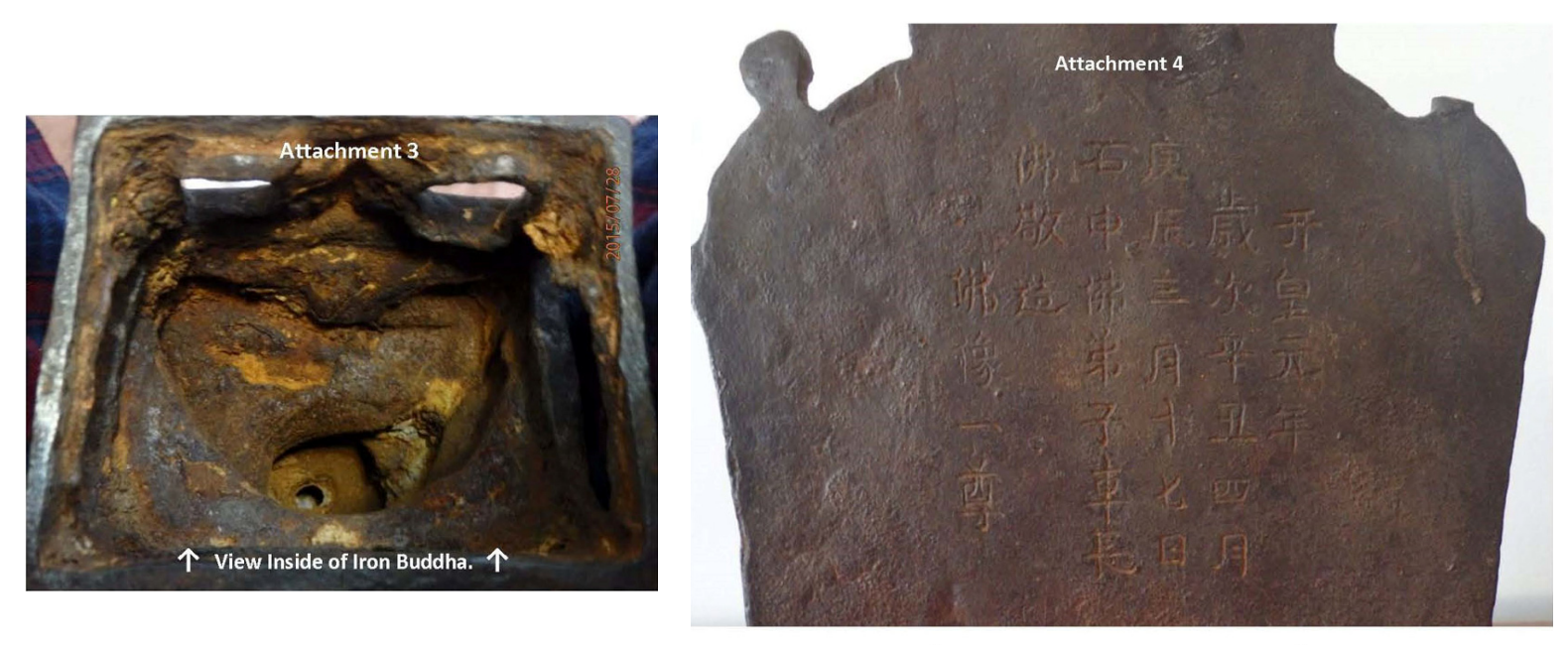

$\uparrow$ Inscription on Back of Iron Buddha $\uparrow$ 
Appendix 5. 'Early Sui' Dynastic Calendar Dates (Buddhist Studies Authority Database)

$1^{\text {st }}$ Year of Kai Huang Reign Period - A XinChou Year (581)

\begin{tabular}{|c|c|}
\hline $\begin{array}{l}+0581-03-06 \sim \\
+0582-02-10 \\
\\
(19333311933672)\end{array}$ & $\begin{array}{l}\text { 隋 文帝 } \\
\text { 開皇 元年（辛 } \\
\text { 丑） }\end{array}$ \\
\hline
\end{tabular}

1st Day of $4^{\text {th }}$ Month $-A$ GengChen Day $+0581-05-21 \sim+0581$ - 隋 文帝 06-19 (19334071933436)

開皇 元年（辛

丑)

四月庚辰朔

$1^{\text {th }}$ Day of $3^{\text {rd }}$ Month - A DingYou Day, not a BingShen Day

$[$ 朝代: 隋 $] \rightarrow[$ 帝號: 文帝 $] \rightarrow[$ 年號: 開皇 $] \rightarrow[1$ 年 $] \rightarrow[三$ 月 $]$

\begin{tabular}{|c|c|}
\hline $\begin{array}{l}+0581-04- \\
07 \\
(1933363) \\
\text { (丙申) } \\
{[\bigcirc \text { 月偏 }} \\
\text { 食] }\end{array}$ & $\begin{array}{l}\text { 隋 文帝 } \\
\text { 開皇 元年 } \\
\text { (辛丑) } \\
\text { 三月十六日 } \\
\text { (丙申) }\end{array}$ \\
\hline $\begin{array}{l}+0581-04- \\
08 \\
\text { (1933364) } \\
\text { (丁酉) }\end{array}$ & $\begin{array}{l}\text { 隋 文帝 } \\
\text { 開皇 元年 } \\
\text { (辛丑) } \\
\text { 三月十七日 } \\
\text { (丁酉) }\end{array}$ \\
\hline
\end{tabular}

(Compiled by author from multiple pages of Buddhist Studies Authority Database). 
Appendix 6. 'Early Sui' Dynastic Calendar Dates (Chen Yuan's Table 1) (Chen Yuan 222)

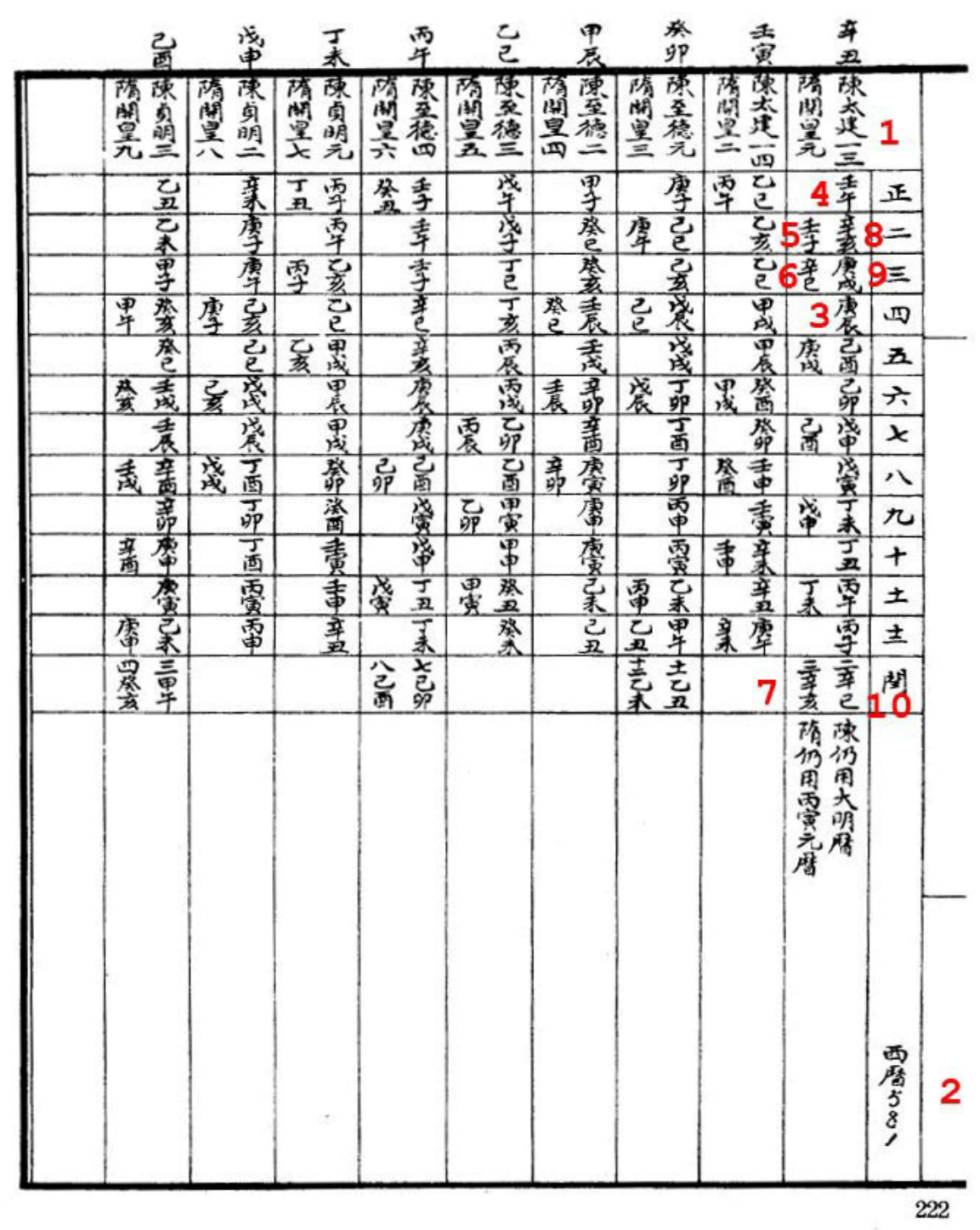


Appendix 6a. 'Early Sui’ Dynastic Calendar Dates (Chen Yuan's Table 2) (Chen Yuan 80)

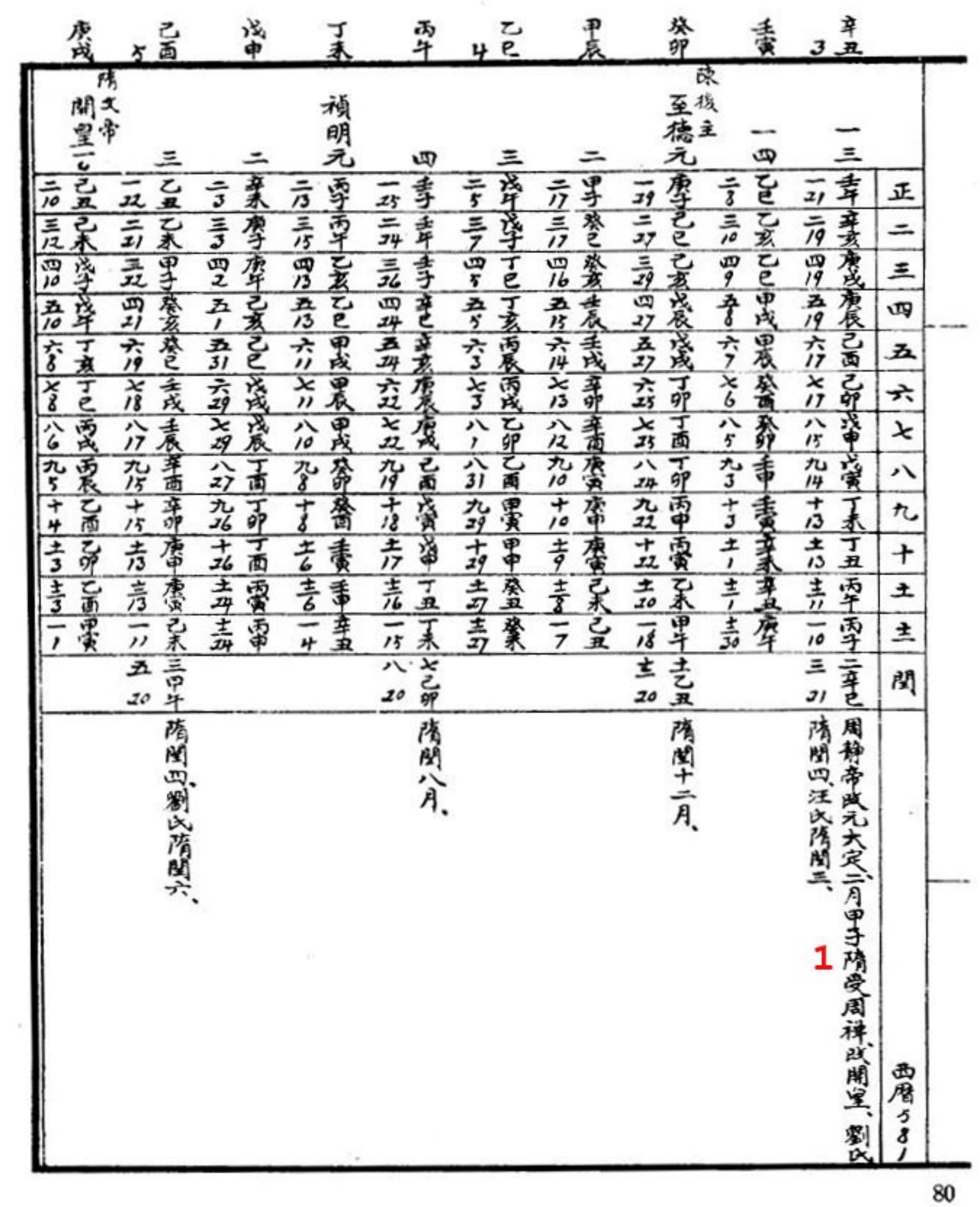


Appendix 7. Sui Dynasty ‘Stone Guanyin’ \& Close-Up of Inscription

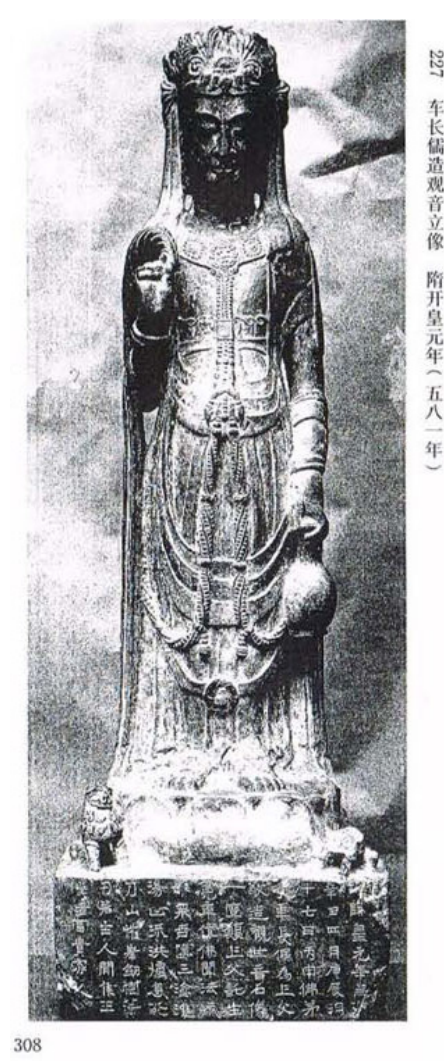

(Jin Shen 308)

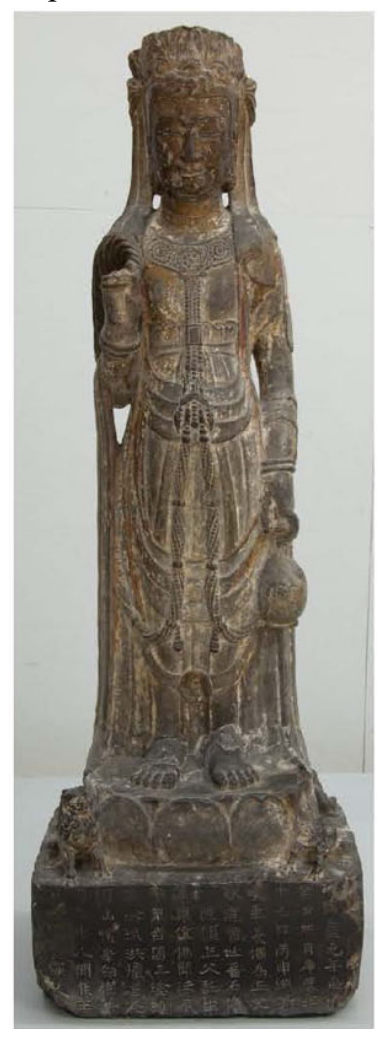

(Jin Shen 308)

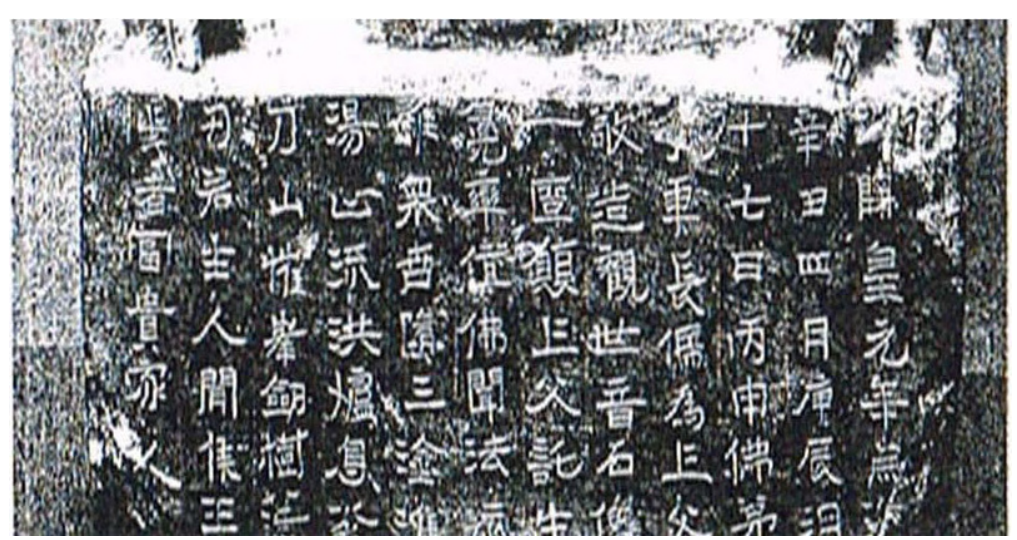

(Enlargement [by author] of base from Jin Shen 308) 
Appendix 8. Detroit Institute of Arts ‘Stone Guanyin' Fact Sheet

Guanyin (26.128)

- Sui Dynasty sculpture

- Limestone with traces of gilt and polychrome

- $581 \mathrm{CE}$

- Description: "Standing male figure dressed in long gown embellished with jewels. Subject wears

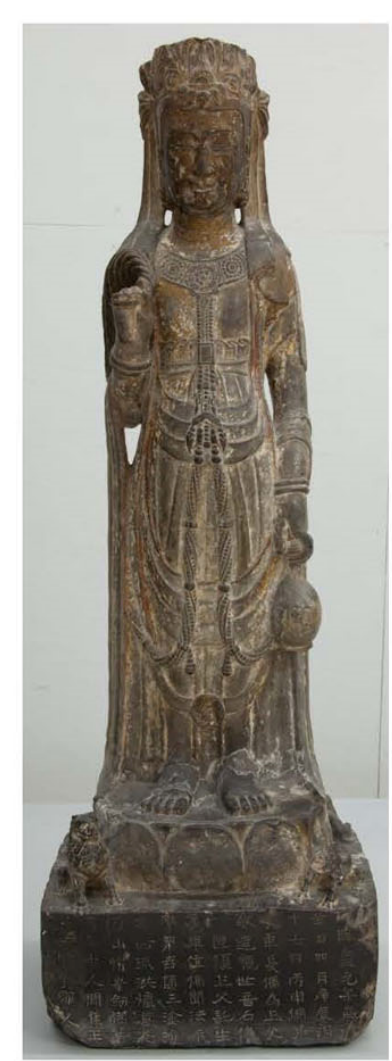
elaborate crown and raises right hand in gesture of greeting (or benediction?)."

- City of Detroit purchase from dealer Ton-Ying

Curatorial Remarks:

- Yutaka Fujioka, associate professor of art history at Osaka University and a specialist in Chinese Buddhist sculpture, questioned the authenticity of the inscription on this work because Sui inscriptions typically start on the proper right side. Fujioka also commented that the carving of one of the fleshy folds on the neck is a little too sharp (possibly retouched?). Fujioka studied the sculpture in storage in January, 2005.

- Jan Stuart, Chinese specialist at the Freer-Sackler also felt that the sculpture was Sui but the inscription was a later addition.

- Notes based on comments by Stanley Abe, Associate Professor, Dept. of Art, Art History, and Visual Studies at Duke University, and specialist on Chinese sculpture. Prof. Abe examined the sculpture in storage on Nov. 28, 2007: Inscription begins below the damage on the proper top left corner of base, indicating that the inscription is likely not original.

- This view was confirmed by Sato Chisui, professor emeritus, Ryukoku University, Ishimatsu Hinako, Seisen University, Lecturer, Ichikawa Yoshifumi, Associate Professor, Ryukoku University, Okada Ken, National Research Institute for Cultural Properties, Tokyo and Professor Stanley Abe during their visit and viewing on Mai 9, 2016.

- Similar objects

- An object in the Michael B. Weisbrod collection at the Carlyle in 1972 was in the object file. It is a 29 inch $6^{\text {th }}$ century Northern Qi/Sui Dynasty limestone Guanyin

- Publications: mentioned in the DIA Bulletin vol. 8 no 41927 p. 40.

\section{Copyrights}

Copyright for this article is retained by the author(s), with first publication rights granted to the journal.

This is an open-access article distributed under the terms and conditions of the Creative Commons Attribution license (http://creativecommons.org/licenses/by/3.0/). 